\title{
Effects of Teaching Presentation Methods and Visual and Auditory Working Memory Capacity on Young Children's Learning Effectiveness
}

\author{
Yun Hyun Pack ${ }^{1}$, Na Ya Choi ${ }^{2}$, Bokyung Kim ${ }^{3}$ \\ Ph. D., Interdisciplinary Program in Early Childhood Education, College of Education, Seoul National University, Seoul, Korea ${ }^{1}$ \\ Professor, Department of Child Development and Family Studies, College of Human Ecology, Seoul National University, Seoul, Korea² \\ Research professor of humanities and sociology, Yonsei Institute of Convergence Technology, Yonsei University, Incheon, Korea ${ }^{3}$
교수자료의 정보제시 방식과 유아의 시각 · 청각 작업기억 용량이 유아의 학습효과에 미치는 영향 \\ 박윤현 ${ }^{1}$ 최나야 ${ }^{2}$, 김보경 ${ }^{3}$ \\ 서울대학교 교육학 박사 ${ }^{1}$, 서울대학교 아동가족학과 교술, 연세대학교 인문사회학술연구교수 ${ }^{3}$
}

Objectives: This study investigates the effects of teaching material presentation methods and young children's visual and auditory working memory capacity on their learning effectiveness. It also suggests effective instructional design and teaching-learning methods suitable for children's information processing characteristics.

Methods: Participants included 86 five-year-old children enrolled in kindergartens in Seoul, Gyeonggi, Incheon, and Daejeon. Three categories of teaching materials with different presentation methods were created. Participants were randomly assigned to one of the category groups, and participated in learning activities. After the activities, learning effectiveness, working memory, and attention were measured. Data were analyzed using SPSS 20.0.

Results: Results indicated that children's learning effectiveness differed according to the teaching material presentation method. Higher learning effectiveness was observed when auditory and visual information was presented concurrently rather than sequentially, but learning was not affected by the sequential order. The groups with larger auditory working memory capacity and larger visual working memory capacity achieved higher learning effectiveness than did their respective counterparts. Additionally, learning effectiveness was greater for children with larger auditory working memory capacity when presented with auditory information before visual, and for those with larger visual working memory capacity when presented with visual information before auditory.

Conclusion: The study results enhance foundational knowledge related to individual differences in young children's visual and auditory information processing abilities. Moreover, this study has practical implications for developing instructional materials and proposals suitable for young children's individual information processing characteristics.

Keywords: teaching materials, information presentation method, visual and auditory working memory, learning effectiveness

Corresponding Author: Na Ya Choi, Professor, Department of Child Development and Family Studies, College of Human Ecology, Seoul National University, 1 Gwanak-ro, Gwanak-gu, Seoul, Korea

E-mail: choinaya@snu.ac.kr
(C)The Korean Association of Child Studies

This is an Open Access article distributed under the terms of the Creative Commons Attribution Non-Commercial License (http:// creativecommons.org/licenses/by-nc/4.0) which permits unrestricted noncommercial use, distribution, and reproduction in any medium, provided the original work is properly cited. 


\section{Introduction}

오늘날 유아교육은 유아발달에 미치는 중요성에 대한 논의를 넘어 실질적으로 무엇을 어떻게 가르칠 것인가에 대한 논의로 관심이 집중되고 있다(Moon \& Kang, 1995). 유아에게 도움이 되는 수업이 실제로 어떠한 조건을 가져야 하며, 어떠한 수업 방안이 유용한지에 대한 연구와 논의가 이루어져 왔다. 특히, 1980년대에 유아교육의 질적 수준에 대한 논의가 본격적으 로 이루어지기 시작하면서 미국의 전미유아교육협회(National Association for the Education of Young Children [NAEYC])는 발 달에 적합한 실제(Developmentally Appropriate Practice)를 출간 하며 유아의 발달에 적합한 유아교육과정을 구성하고 운영할 것을 제안하였다(NAEYC, 1986). 유아의 발달에 도움이 되는 양질의 유아교육은 유아의 연령에 따른 발달 단계의 수준을 반영해야 하며, 유아의 개인 특성이나 문화적 특성과 같은 개 인차를 모두 고려해야 한다는 것이다. 따라서, 같은 연령 그룹 에 대한 전반적인 교육안과 개별 유아의 흥미와 개성, 욕구 등 을 반영한 교육안의 계획이 고려되어야 한다. 이러한 과정에 서 유아 교사는 전반적인 교육 환경을 준비하고 조성하며, 유 아들을 세심하게 관찰하고 안내하는 중요한 역할을 수행한다 (Kang, 1993; Yoon, 2004).

유아의 개인차 변인은 크게 몇 가지 측면에서 접근할 수 있 다. Korea Institute for Curriculum and Evaluation (1998)은 개인 차를 고려한 교수 설계 시, 크게 학습자의 학습 능력, 학습 동 기 및 흥미, 인지·학습 양식을 고려할 수 있음을 제안하였다. 유아교육 분야에서도 이와 같은 개인차 요소들이 교수-학습 설계에서 다양하게 고려될 수 있는데, 지금까지는 이 중에서 도 유아의 흥미와 관심의 개인차가 현장에서 가장 활발하게 논의되고 교육 실제에 반영되어 왔다. 예를 들어, 프로젝트 접 근법은 유아의 흥미와 관심을 주제선정과 탐색 과정에 잘 반 영하여 유아의 참여와 몰입을 이끌어내는 교수법으로 잘 알려 져 있으며, 유아중심, 놀이중심 교육과정에서도 개별 유아의 흥미와 관심 요소를 최대한 반영하여 운영하고 있다. 이에 반 해, 유아의 발달 수준이나 인지·학습 양식 등의 개인차를 반영 한 유아교육 방안은 그동안 활발하게 연구되거나 적용되지 못 하였다.

그동안 학습자의 개인차를 고려한 교수 방안의 모색은 학 령기 아동 및 청소년의 교육에서 주로 이루어져 왔다. 예를 들 어, Chang (1998)은 집단화 수업 시 수업의 수준을 중간이나 상위 아이들에 맞출 때, 그 이외의 아이들은 수업 대상에서 제 외되어 교육의 효율성이 크게 낮아지는 심각한 문제가 야기
될 수 있음을 지적하였다. 이에 그는 아동의 학습에 영향을 미 치는 다양한 인지적 개인차, 예를 들어, 학습 전략, 인지 양식, 사전지식 등을 교육에서 고려할 것을 제안하였다. 또한, Byun (1999)은 개인차를 고려한 수업 전략들을 좀 더 구체적으로 제 시하였는데, 이러한 전략으로 학습과제의 수준 체크, 학습동 기의 유발, 다양한 강화와 피드백 제공, 다양한 수업매체의 이 용 등을 제안하였다. 이처럼 학령기 교육에서는 학습자의 개 인 특성을 고려한 효과적인 교수 설계에 대해 다양한 연구와 논의가 이어져 왔으나, 아직까지 유아교육에서 이러한 고려와 논의는 매우 부족한 실정이다.

한편, 오늘날 다양한 미디어 매체를 활용한 교육이 활발하 게 이루어지면서, 많은 연구자들은 교육 장면에서 학습자의 학습효과를 높이는 시·청각 정보의 제시 방법과 학습자의 인 지적 처리 특성에 맞는 시·청각 정보의 제시 방안을 제안해 왔다(Do \& Cha, 2008; E.-A. Kim, 2011; Mayer, 2003; Mayer \& Estrella, 2014; Thomas \& McKay, 2010). 이러한 선행연구들은 관련 인지 이론과 인간의 인지처리 시스템 모델을 바탕으로 하였는데, 대표적인 것이 Mayer (2003)의 멀티미디어 설계 원 리와 Baddeley와 Hitch (1974)의 작업기억 모델이다. 먼저, 멀 티미디어 설계 원리는 Mayer가 멀티미디어를 활용한 학습에 서 고려되어야 하는 설계 원리를 기존의 인지 이론들(이중채 널이론, 제한용량 이론, 능동적 처리 이론, 인지부하이론 등) 을 바탕으로 제안한 것으로, 인지부하를 높이는 불필요한 중 복 자극을 줄이는 방법, 전달 내용과 관련한 시·청각 정보들 을 동시에 제시하는 방법 등이 학습의 효과를 높일 수 있음을 제안하였다(E.-J. Kim, Park, \& Kim, 2011; Mayer \& Moreno, 2002). 그 중, 시·청각 정보의 제시 동시성을 강조한 시간인접 의 원리는 대응하는 청각(언어) 정보와 시각 정보를 하나씩 연 속적으로 제시하는 것보다 동시에 제시하는 것이 학습자의 학 습효과를 높일 수 있음을 제안한다.

이는 인간의 인지처리 시스템을 통해 더 구체적으로 설명 될 수 있다. 인지심리학자들은 인간의 다양한 정보처리가 작 업기억이라는 인지 시스템에서 이루어지며, 그 시스템은 몇몇 하위 시스템으로 구성되어 있음을 제안하였다. 대표적인 작업 기억 모델인 Baddeley와 Hitch (1974)의 모델에 따르면, 작업기 억은 청각(언어) 정보를 일시적으로 저장하고 시연을 통해 장 기기억에서 유지하도록 하는 음운론적 회로(phonological loop) 와 시공간 정보를 일시적으로 유지하고 조작하는 시공간잡기 장(visuo-spatial sketchpad), 그리고 이러한 두 하위 시스템으로 부터 온 정보와 장기기억으로부터 온 정보들을 통합하는 중앙 집행기(central executive)로 구성되어 있다. 이러한 시스템에서 
수용된 시·청각 자극들은 소리와 이미지의 형태로 작업기억의 음운론적 회로와 시공간잡기장에서 각각 처리되며, 중앙집행 기에 의해 이렇게 처리된 정보들과 장기기억에 있던 선행지식 들은 결합, 통합되어, 정보 해석의 과정을 거치게 된다(Mayer \& Moreno, 2002, 2003; Park \& Kwon, 2010). 따라서, 어떤 정보 가 청각, 시각 양식으로 동시에 제시되면, 두 가지 감각 양식으 로 정보가 동시에 처리되고, 처리된 정보들이 바로 함께 통합 되면서, 더 깊고 빠른 정보처리가 가능하게 되는 것이다.

Mayer와 Anderson (1992)은 이러한 시간인접의 원리를 제 안하고 실험으로 검증하였으며, Ginns (2006)는 13편의 관련 논문에 대한 메타분석을 통해 시각, 청각 자극이 연달아 제시 되는 경우보다 동시에 제시되는 경우가 학습에 더 효과적임 (standardised mean difference $(\mathrm{d})=0.78$ )을 밝혔다. 이후 많은 연 구자들이 효과적인 교수설계를 할 때 이 원리를 많이 참고하 였지만(Mammarella, Fairfield, \& Di Domenico, 2013; Sorden, 2005; Yue, Kim, Ogawa, Stark, \& Kim, 2013), 이에 대한 추가적 인 재검증, 특히 유아의 학습 상황에서 이에 대한 실증적 재검 증은 거의 이루어지지 못하였다. 선행이론에 따르면, 유아에 게 어떤 개념을 설명할 때 청각 정보와 시각 정보를 동시에 제 공하는 것이 학습효과를 높여줄 것으로 예상되지만, 유아의 정보처리 발달의 수준은 청소년이나 성인에 비해 훨씬 낮은 수준이기에 청각적, 시각적 처리를 하나씩 순차적으로 하는 것이 인지부하를 낮춰 유아의 정보처리 효율성을 높일 가능성 도 제기된다. 따라서, 이에 대한 조사와 확인이 필요하다.

청각, 시각 정보의 처리는 유아의 청각, 시각 작업기억과 매 우 밀접한 관련을 가지고 있다. 많은 연구자들은 작업기억 공 간의 크기가 정보처리 효율성이나 정보처리 능력과 밀접하게 관련되어 있음을 밝혀왔다(Case, 1985; Daneman \& Carpenter, 1980; Gathercole, Alloway, Willis, \& Adams, 2006). 작업기억 용 량이 증가한다는 것은 어려운 인지 과제를 해결할 때, 정보 들을 일시적으로 저장할 수 있는 공간이 증가함을 의미하며, 정보를 저장하고 남는 공간을 정보의 조작 및 처리에 이용함 으로써 정보를 보다 효율적으로 처리할 수 있음을 의미한다 (Case, 1985). 따라서, 어떤 개인이 청각 또는 시각 작업기억 용량이 크다면, 그 양식의 정보를 훨씬 효과적이고 효율적으 로 처리할 수 있을 것이다. 작업기억은 일반적으로 4세에서 8 세 사이에 크게 발달하며, 발달의 속도, 발달 수준에서 개인차 가 존재한다(Gathercole, 1999; Gathercole, Pickering, Ambridge, \& Wearing, 2004; Nevo \& Breznitz, 2013; Teixeira, Zachi, Roque, Taub, \& Ventura, 2011). 또한, 청각(언어) 정보와 시공간 정보 를 다루는 두 종류의 하위 작업기억은 발달의 궤를 같이 하
지 않으며, 서로 독립적으로 발달함이 밝혀져 왔다(Pickering, Gathercole, \& Peaker, 1998). 따라서, 청각 작업기억과 시각 작 업기억의 발달 수준은 유아별로 각각 다를 수 있다.

이처럼 청각, 시각 작업기억이 서로 독립적으로 발달하여 유아마다 청각, 시각 작업기억의 발달 수준은 다를 수 있지만 (Pickering et al., 1998; Smyth \& Scholey, 1996), 전체적으로 유아 기에 특정 유형의 작업기억이 발달 우위에 있다는 보고는 나오 지 않고 있다. 따라서 만약 청각 정보와 시각 정보가 순차적으 로 제시된다면, 제시 순서(청각-시각 vs. 시각-청각)에 따라 전 체 유아들의 학습효과 평균은 달라지지 않을 것으로 예상된다. 그러나 아직 이에 대해 조사되거나 검증된 바가 거의 없어 관 련 조사가 요구된다. 이에 이 연구에서는 유아의 학습에서 청 각 정보와 시각 정보가 순차적으로 제시될 때, 그 순서에 따라 유아의 학습효과가 달라지는지 함께 살펴보고자 하였다.

앞서 언급한 바와 같이, 유아의 작업기억 중 청각적(언어 적) 작업기억과 시공간적 작업기억은 서로 독립적으로 발달 하기 때문에 유아별로 더 효과적으로 처리할 수 있는 정보의 유형(청각 또는 시각)은 달라질 수 있다(Pickering et al., 1998; Smyth \& Scholey, 1996). 선행연구들은 청각(언어) 정보를 효율 적으로 처리하는 학습자와 시각 정보를 효율적으로 처리하는 학습자가 각각 그에 맞는 정보양식 또는 정보제시 방식을 제 공받았을 때 학습의 효과가 높아짐을 확인하였다. 예를 들어, Do와 Cha (2008)의 연구에서는 시공간 작업기억 용량이 큰 그 룹과 작은 그룹의 초등학생을 선발하여 세 종류의 영어단어 학습 조건(설명을 단어로만 제공/ 동영상과 함께 제공/ 그림과 함께 제공)에서 학생들의 학습효과를 확인하였다. 이 연구에 서 동영상 제공 조건은 시공간 작업기억 용량이 큰 집단에서 만 효과를 보였는데, 연구자들은 이러한 결과를 순간순간 빠 르게 변화하는 동적인 자극들이 학습자의 시공간 작업기억의 부하를 높여 시공간 작업기억 용량이 큰 학습자에게만 그 효 과가 나타난 것으로 해석하였다. 또한, E.-A. Kim (2011)의 연 구에서는 대학생 참여자들을 학습양식 검사를 통해 언어학습 자(언어 정보 선호)와 시각학습자(시각 정보 선호)로 나누고, 참여자들의 그림 및 단어분류 수행을 살펴보았다. 이 연구에 서 시각학습자의 그림분류 과제 수행시간은 단어분류 과제 수 행시간보다 더 짧게 나타났다. 또한, 함께 측정한 뇌파 분석 결 과, 시각학습자는 단어분류과제의 수행 시 감마파의 상대파워 가 좌반구 베르니케 영역뿐 아니라 우반구 측두엽에서도 강하 게 나타나 언어이해와 함께 시공간적 처리가 이루어짐을 확인 하였다. 이러한 결과들은 시각학습자들이 청각 정보보다 시각 정보처리에 더 강하며, 청각적으로 처리될 수 있는 단어분류 
과제를 수행할 때에도 단어를 이미지로 변환하여 처리할 수 있음을 보여준다.

또한, Thomas와 McKay (2010)의 연구에서는 대학생 학습자 의 인지적 스타일과 교수디자인 효과의 관계를 살펴보았는데, 학생들의 인지적 스타일과 교수자료의 제시 형식이 일치하였 을 때 학생들의 학습효과가 높아졌다. 즉, 언어점수가 높은 학 생들은 글로만 제시된 자료로 학습하였을 때, 시공간 점수가 높은 학생들은 글과 그림이 함께 제시된 자료로 학습하였을 때 기억 점수가 높게 나타났다. 이러한 결과는 아동을 대상으 로 한 몇몇 선행연구들에서도 유사하게 나타났다(Grigorenko \& Sternberg, 1995; Riding \& Ashmore, 1980; Riding \& Rayner, 1998). 학습자료가 아동이 선호하는 정보 양식(그림, 도표/ 글, 말)으로 제시될 때 아동의 학습 성취가 더 높게 나타났다. 이 러한 연구들은 교수 자료가 학생들의 학습양식, 즉 언어적, 시 공간적 인지 스타일에 맞을 때 학습이 향상된다는 증거를 제 시한다. 뿐만 아니라, Do와 Hwang (2006)은 멀티미디어 학습 에서 학습자의 인지양식과 제시되는 정보제시 방식이 일치할 때, 인지 수행이 더 높아짐을 확인하였다. 이 연구에서 시각형 학습자는 그림 정보를 먼저 제시하는 경우, 언어형 학습자는 언어 정보를 먼저 제시하는 경우 학습 효과성이 높아졌다. 이 는 학습자의 인지양식에 따라 정보제시 순서가 다른 학습자료 들의 인지부하가 달라질 수 있으며, 이에 따라 학습자 개인에 더 적합한 교수자료들이 존재할 수 있음을 시사한다.

이러한 선행연구들은 유아를 위한 교수-학습 방법을 설계 할 때, 청각 및 시각 작업기억 용량의 개인차, 즉 작업기억 내 에서 더 효과적으로 처리되는 감각 양식의 개인차도 고려할 필요성을 제안한다. 그러나 아직 유아를 대상으로 한 관련 연 구가 거의 진행되지 않아, 작업기억 양식별 용량의 개인차를 고려한 교수 방안이 개별 유아들의 학습에 효과가 있는지 확 인되지 않았다. 따라서, 이 연구에서는 유아의 청각 작업기억 용량과 시각 작업기억 용량의 수준에 따라 유아들에게 더 적 합한 자료제시 방법은 무엇인지 확인할 필요가 있다.

이와 같은 연구 필요성에 따라, 이 연구에서는 교수자료의 정보제시 방식과 유아의 청각, 시각 작업기억 용량이 유아의 학습효과에 미치는 영향을 살펴보고, 개별 유아들의 작업기 억 발달 특성(감각 양식별)에 따라 효과적인 학습을 도모하는 교수안에 대해 제안하고자 하였다. 한편, 이 연구에서는 유아 의 학습효과에 영향을 미칠 수 있는 다른 변인을 통제하는 것 을 고려하고자 하였다. 주의 능력은 인간이 정보를 수용하고, 처리하고, 해석하는 데 바탕이 되는 기초적인 인지 능력으로 (Dehaene, Changeux, Naccache, Sackur, \& Sergent, 2006), 교수-
학습 상황에서, 특히 방해자극이 있는 환경에서 유아의 학습 효과에 영향을 미치는 영향 요인이 될 수 있다. 따라서, 이 연 구에서는 교수자료의 정보제시 방식이 유아의 학습효과에 미 치는 영향을 보다 정확하게 측정하기 위해, 이와 같은 유아의 주의 능력의 개인차를 통제하고자 하였다. 이러한 연구는 유 아의 인지적 처리 특성에 대한 기초 학문적 정보를 제공할 뿐 아니라, 유아교육 현장에서 활용할 수 있는 실용적 교수-학습 방안도 제시해줄 수 있을 것이다. 이 연구의 연구문제는 다음 과 같다.

\section{연구문제 1}

교수자료의 정보제시 방식과 유아의 작업기억 양식별 용량에 따른 학습효과는 어떠한가?

1-1. 교수자료의 정보제시 방식(청각먼저 제시, 시각먼저 제시, 동시 제시)에 따른 유아의 학습효과는 어떠한가?

1-2. 유아의 청각.시각 작업기억 용량에 따른 학습효과는 어떠한가?

1-3. 교수자료의 청각 시각 정보제시 방식과 유아의 청 각.시각 작업기억 용량 간 상호작용 효과가 나타나는가?

\section{Methods}

\section{연구대상}

이 연구는 서울, 경기, 인천, 대전 지역의 유치원에 다니는 만 5 세 유아 86명을 대상으로 하였다. 유아의 작업기억은 만 3-5세 에 크게 발달하며, 만 5 세는 유아기 중에서도 작업기억이 가장 높은 수준으로 발달해 있는 시기이다. 따라서, 이 연구의 연구 문제를 깊이 있게 조사하기에 적합한 시기를 만 5 세로 보고 연 구대상을 선정하였다. 또한, 연구 결과의 일반화를 위해 참여 유아는 담임교사가 인지적, 정서적으로 특별한 이상이 없다고 추천한 유아들을 대상으로 하였다. 각 기관에서 모집된 모든 참여 유아들은 난수표를 이용하여 3 개의 연구 집단 중 한 집 단에 무선 할당되었다. 연구 집단별 연구대상 유아의 구성은 Table 1 과 같다. 
Table 1

Composition of Young Children as Research Subjects by Group

\begin{tabular}{|c|c|c|c|c|}
\hline Group & \multicolumn{2}{|c|}{ Gender } & All & $\begin{array}{c}\text { Average age } \\
\text { (Months) }\end{array}$ \\
\hline $\begin{array}{l}\text { Group } 1 \\
\text { (Simultaneous presentation) }\end{array}$ & 14 & 17 & 31 & 75.19 \\
\hline $\begin{array}{l}\text { Group } 2 \\
\text { (Auditory-first presentation) }\end{array}$ & 14 & 14 & 28 & 73.43 \\
\hline Total & 40 & 46 & 86 & 74.56 \\
\hline
\end{tabular}

\section{연구도구}

교수자료

교수자료는 과학교과 영역의 '천둥과 번개', '무지개'를 주제 로 각각 구성하였다. 많은 연구들은 다양한 교수 방법이 학습 자의 학습효과에 미치는 영향을 조사하면서 물리, 화학, 생물, 지구과학과 관련한 다양한 과학 내용(도르래의 원리, 시냅스 주변의 화학작용, 심장의 구조와 기능, 화산분출의 원리 등) 을 학습 자료로 제작하여 학습자에게 제시하였다(De Koning, Tabbers, Rikers, \& Paas, 2010; Eitel, Scheiter, Schüler, Nyström, \& Holmqvist, 2013; Florax \& Ploetzner, 2010; Jaeger \& Wiley, 2014). 이러한 과학 주제는 문학이나 예술 주제와 달리 현상에 대한 사실 및 원리가 내포되어 있어, 학습 후 학습자의 내용 이 해도를 보다 명확하게 측정하기에 적합할 수 있다. 또한, 과학 교과 중에서도 지구과학 영역은 우리 주변에서 볼 수 있는 다 양한 자연현상을 포함하기에, 유아도 이를 일상에서 직접 접 하고 경험할 수 있어 유아의 관심과 호기심을 끌기에 좋은 주 제가 될 수 있다.

이 연구에서 한 종류가 아닌 두 종류의 교수자료를 구성한 것은 유아의 수행 데이터 측정의 안정성을 위한 것이었다. 이 연구에서는 유아당 두 번 학습 활동을 하고 그 수행 결과의 평 균을 유아의 데이터로 기록함으로써 유아의 수행 측정의 안정 성을 높이고자 하였다.

\section{스크립트}

교수자료의 스크립트는 유아교육 앱(오디오클립)의 자연과학 동화(궁금해 에디, 천둥번개는 왜 생길까? 무지개는 왜 생길 까?)와 초등학교 5,6 학년 과학의 천둥과 번개, 무지개 관련 내
용(Ministry of Education, 2019a, 2019b)을 참고로 만 5세 유아 의 수준에 맞추어 구성하였다. 어려운 개념적 내용을 최대한 쉬운 설명과 비유적 표현으로 전달하여 유아가 충분히 이해할 수 있도록 구성하였다. 이 연구의 스크립트는 유아교육 전문 가 2인과 유아교사 2인을 통해 타당도를 검증받았다. 스크립 트의 타당도 검증을 위해 연구자는 전문가들에게 스크립트의 난이도 적합성, 내용 적합성, 표현 적합성 여부를 3점 척도로 (적합/보통/부적합) 평가하고, 부적합한 부분에 대해서는 비 판적 의견을 함께 기재해줄 것을 요청하였다. 연구자는 전문 가들의 피드백을 반영하여 스크립트를 수정, 보완하였다. 예 를 들어, 스크립트의 문장을 더 단순하게 수정하고, 자세한 설 명을 위해 추가한 불필요한 비유를 제외하였으며, 도입과 마 무리 부분의 길이를 두 주제에서 유사하게 맞추었다. 이렇게 수정, 보완된 스크립트는 한 번 더 전문가들의 검토를 거처 최 종 스크립트로 구성되었다. 스크립트의 전체적인 내용과 구성 은 Table 2와 같다.

이 스크립트는 유아교사 1 인에 의해 명확한 발음과 적절 한 속도로 녹음되었고, 유아교육 전문가 2 인의 검토를 받아 최 종 녹음 파일이 제작되었다. 녹음된 최종 음성 파일 $(\mathrm{mp} 4)$ 은 천 둥과 번개 스크립트가 총 3 분 45 초, 하늘 위의 무지개 스크립 트가 총 3 분 59초였으며, 이들은 조건별 교수자료 슬라이드에 삽입되었다.

\section{시각자료}

이 연구에서 시각자료는 스크립트 내의 각 내용을 더 잘 이해 할 수 있도록 돕는 이미지로 제작하여 구성하였다. 각 주제별 로 도입, 내용 1 , 내용 2 , 내용 3 , 마무리에 대한 시각자료를 구성 하였다. 연구 조건별 시각자료는 일러스트 전문가 1 인에 의해 제작되었고, 유아교육 전문가 2 인과 유아교사 2 인에게 타당 
Table 2

Content and Composition of the Teaching Material Scripts

\begin{tabular}{|c|c|c|}
\hline Title & Content & $\begin{array}{l}\text { Composition } \\
\text { (No. of words) }\end{array}$ \\
\hline \multirow[t]{3}{*}{ Thunder and lightning } & I'm scared of thunder and lightning! & Introduction (65) \\
\hline & Why does lightning flash? & Content 2 (41) \\
\hline & Why does thunder rumble after a lightning flash? & Content 3 (118) \\
\hline \multirow{3}{*}{ Rainbow in the sky } & $\begin{array}{l}\text { I can see different colors in the rainbow } \\
\text { (sunlight and water drops). }\end{array}$ & Content $1(80)$ \\
\hline & What causes different colors in the rainbow? & Content 2 (56) \\
\hline & There are countless colors in the rainbow. & Content 3 (65) \\
\hline
\end{tabular}

도를 검증받았다. 연구자는 전문가들에게 시각자료의 명료성, 표현의 적절성 등을 3 점 척도로(적합/보통/부적합) 평가하고, 적합하지 않은 부분에 대해서는 비판적 의견도 함께 기재해 줄 것을 요청하였다. 연구자는 이러한 전문가의 평가와 의견 을 바탕으로 시각자료를 수정, 보완하였다. 예를 들어, 시각자 료를 실사에 가까운 이미지에서 조금 더 단순한 이미지로 수 정하였으며, 유아가 스크립트의 내용을 더 잘 이해할 수 있도 록 구름의 크기 변화, 얼음 알갱이의 이동, 빛의 굴절 표현, 마 무리 이미지의 구성 등을 수정, 보완하였다. 이렇게 제작된 최 종 시각자료는 조건별 교수자료 슬라이드에 이미지로 삽입하 여 이용하였다.

\section{교수자료의 구성}

이 연구의 교수자료는 다음과 같이 구성되었다. 먼저, 집단 1 의 교수자료는 언어적 설명과 시각 이미지가 동시에 제시된 것으로, 연구자는 파워포인트의 슬라이드 5장에 각각 도입, 내 용1, 내용2, 내용3, 마무리에 해당하는 이미지를 전체 화면으 로 삽입하고, 각 슬라이드에 해당하는 오디오 파일을 각각 삽 입하였다. 집단 2의 교수자료는 언어적 설명이 시각 이미지보 다 먼저 제시된 것으로, 연구자는 내용 1 , 내용 2 , 내용 3 , 마무리 부분을 각각 빈화면 + 오디오 $\rightarrow$ 이미지의 순서로 구성하였다. 집단 3의 교수자료는 시각 이미지가 언어적 설명보다 먼저 제 시된 것으로, 연구자는 내용 1 , 내용 2 , 내용 3 , 마무리 부분을 각 각 이미지 $\rightarrow$ 빈화면 + 오디오의 순서로 구성하였다. 도입 이 미지는 스크립트의 제목을 간단하게 제시한 것으로 교수 내용 과는 큰 관련이 없다. 이에 집단 2 와 집단 3 의 유아들의 과제
집중 시간을 고려하여 도입부는 언어적 설명만을 제시하였다. 집단 2 와 집단 3 의 교수자료 구성 예시는 Table 3 과 같다.

집단 1 의 교수자료는 한 화면에 시각 이미지와 오디오가 함 께 포함되어 있어, 오디오 나래이션이 끝나면 다음 화면으로 넘어가도록 하였다. 집단 2 와 집단 3 의 교수자료에서는 빈화 면과 오디오가 제시되는 경우 나래이션이 끝나면 다음 화면으 로 넘어가고, 시각 이미지만 제시되는 경우 5 초 동안 유아에게 제시될 수 있도록 하였다. 연구자는 클릭을 통해 다음 슬라이 드로 넘어가도록 설정하였다. 이 연구에서 제작한 연구 집단 별 교수자료는 유아교육 전문가 2인과 유아교사 2인에게 타 당도를 검증받았다. 연구자는 전문가들에게 교수자료의 구성 적합성(자료 제시 시간 등), 난이도 적합성, 내용 적합성 등에 대한 평가(3점 척도로)와 비판적 의견을 요청하였고, 이를 바 탕으로 각 조건별 교수자료의 구성이 적절함을 확인하였다. 이렇게 제작된 교수자료는 예비조사에서 그 적절성을 다시 한 번 검토하여, 최종적으로 본 조사에 이용하였다.

\section{학습효과 측정 도구}

학습효과는 학습 활동을 통해 기대하는 목표나 목적을 실제로 완벽하게 달성했는지를 말한다(T. G. Kim, 2006). 이 연구에서 학습효과는 유아가 학습 내용을 교수자료를 통해 모두 전달받 은 후, 유아가 사실 문항 및 추론 문항에서 응답한 결과의 수준 으로 조작적으로 정의하였다. 이 연구에서는 이러한 학습효과 를 측정할 수 있는 도구를 제작하기 위해 유아의 내용 기억을 측정하는 사실 문항들과 유아의 내용 이해(추론적 이해)를 측 정하는 추론 문항들을 구성하였다. 
Table 3

Example of Composition of Teaching Materials for Group 2 and 3

Group 2 (Auditory-first presentation)

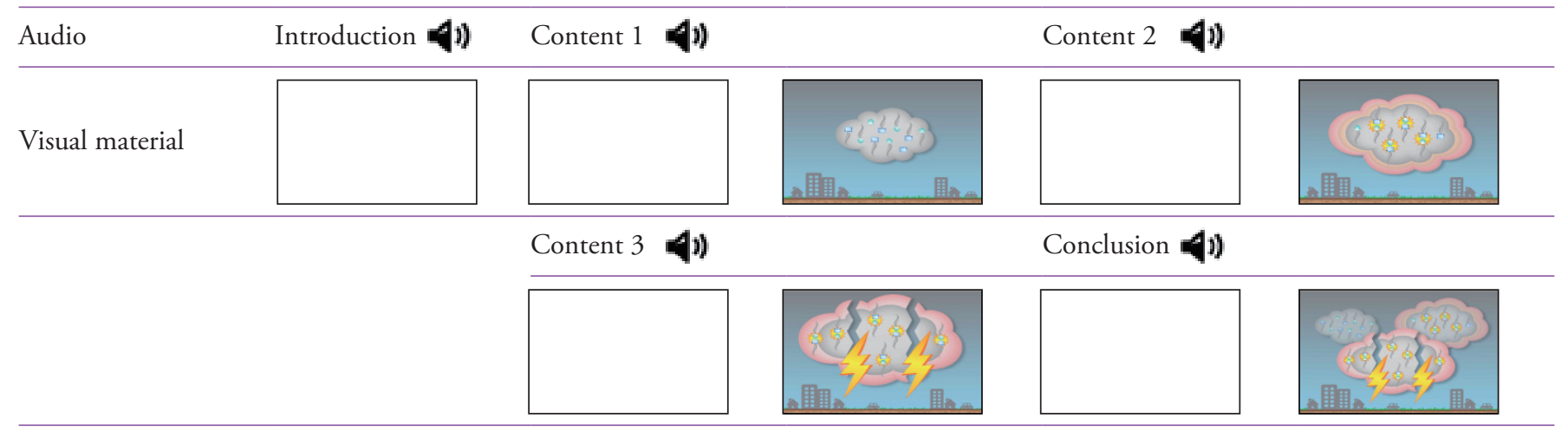

Group 3 (Visual-first presentation)

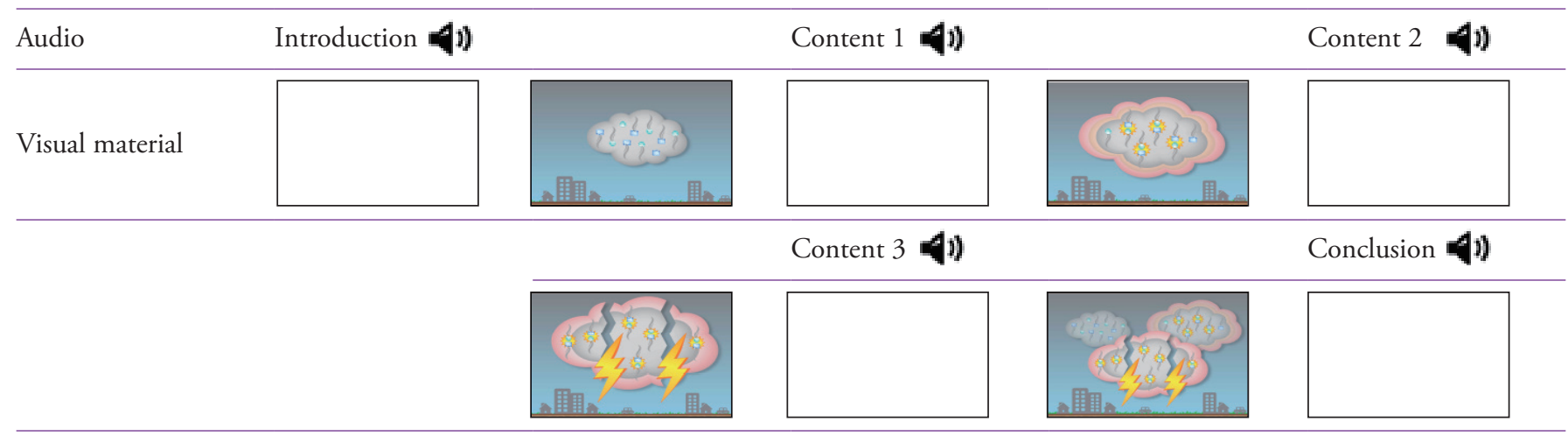

사실 문항은 두 종류의 학습 스크립트에 포함된 중심 내용 들을 바탕으로 연구자가 개발하였다(스크립트당 6문항). 예를 들어, 천둥과 번개 스크립트의 사실 문항은 "구름 속에는 무엇 이 들어있나요?” 등의 문항을, 하늘 위의 무지개 스크립트의 사실 문항은 "햇빛이 무엇에 닿으면 햇빛 속에 들어있는 것을 볼 수 있나요?” 등의 문항을 포함하였다. 사실 문항에서는 유 아의 대답이 맞으면 2점, 틀리면 0점의 점수를 부여하고(추론 문항과 문항당 점수의 범위를 같게 함), 전체 문항의 총점을 합산하여 유아의 사실 문항 점수로 계산하였다.

추론 문항은 스크립트를 통해 직접적으로 전달된 내용은 아니지만, 유아가 그 내용을 충분히 이해한다면 유추하여 대 답할 수 있는 문항들로 구성하였다(스크립트당 4문항). 예를 들어, 천둥과 번개 스크립트의 추론 문항은 "구름 안에 에어컨 이 있어서 시원하게 해줄 수 있다면, 그 구름 속에서 천둥이 칠 수 있을까요? 왜 그렇게 생각하나요?” 등의 문항을 포함하였 고, 하늘 위의 무지개 스크립트의 추론 문항은 "무지개는 비가 내리고 하늘이 깜깜한 상황에서 볼 수 있을까요? 왜 그렇게 생 각하나요?” 등의 문항을 포함하였다. 추론 문항에서는 유아의
응답에 대해 “왜 그렇게 생각하나요?”의 질문을 추가하여 유 아의 답변에 대한 이유를 함께 듣고 이를 채점에 반영하였다. 추론 문항에서는 유아의 답변이 완전하게 맞으면 2점, 완전하 게 맞지는 않지만 맞는 내용이 포함되면 1점, 틀리면 0점의 점 수를 부여하고, 전체 문항의 총점을 합산하여 유아의 추론 문 항 점수로 계산하였다. 이 연구에서 학습효과 점수의 범위는 0-20점, 총점은 20점(사실 12점, 추론 8점)이었다.

학습효과 도구의 평가 문항들은 유아교육학 전문가 2인을 통해 내용 타당도를 검증받았다. 연구자는 전문가들에게 각 스크립트의 학습효과 문항의 구성 적합성, 난이도 적합성 등 을 3점 척도(적합/보통/부적합)로 평가해줄 것을 요청하였고, 부적합하거나 수정이 필요한 문항에 대해서는 비판적 의견을 함께 보내줄 것을 요청하였다. 연구자는 전문가들의 피드백 을 반영하여 학습효과 문항들을 수정, 보완하였다. 예를 들어, “무지개는 햇빛이 쨍쨍 비추는 날에 볼 수 있을까요?”의 문항 을 "무지개는 햇빛이 쨍쨍 비춰서 물방울이 사라진 날에 볼 수 있을까요?”의 문항으로 수정하였다. 이렇게 수정, 보완한 학습 효과 도구는 예비조사에서 검사 문항의 적절성을 한 번 더 확 
인한 후 최종 도구로 이용하였다.

\section{작업기억 측정 도구}

이 연구에서는 유아의 청각 작업기억 용량을 측정하기 위해 숫자회상과제를 이용하였다(J. Y. Kim \& Baek, 2007; Shin, Do, $\mathrm{Kim}, \&$ Park, 2010). 숫자회상과제는 두 가지 하위 과제(바로 따라하기, 거꾸로 따라하기)로 구성되었다. 바로/거꾸로 따라 하기 과제에서는 연구자가 0 부터 9 까지의 숫자를 일정한 간 격으로 불러주면 유아가 이를 그대로/거꾸로 따라 말하도록 하였다. 숫자의 폭은 2 부터 7 까지로 구성되고 각각 2회씩 실 시하였다. 연구자는 각 시행별로 유아의 응답이 정답일 경우 1 , 오답일 경우 0 을 기록지에 기록하였다.

또한, 유아의 시각 작업기억 용량을 측정하기 위해 E-prime software (Psychology Software Tools, Sharpsburg, PA)를 이용하여 코시기억과제(corsi memory task)를 제작하였다. 이 과제는 두 가지 하위 과제(바로 가리키기, 거꾸로 가리키기)로 구성되었 다. 바로/거꾸로 가리키기 과제에서는 컴퓨터 화면에 제시된 9 개의 네모 중 하나씩 1 초 간격으로 색이 변하면 유아가 이를 모두 본 후 손가락으로 네모를 같은/반대의 순서로 하나씩 가 리키도록 하였다. 네모의 개수는 2 개에서 시작하여 7 개까지 늘려가며 각각 2회씩 실시하였다. 연구자는 각 시행별로 유아 의 응답이 정답일 경우 마우스 왼쪽 버튼을, 오답일 경우 마우 스 오른쪽 버튼을 클릭하여 E-prime 프로그램에 유아의 반응 을 기록하였고, 이를 점수화 하여(정답일 경우 1 , 오답일 경우 0) 통계 분석에 이용하였다.

\section{주의 측정 도구}

유아의 주의를 측정하는 도구는 E-prime 프로그램을 이용하 여 개발하였다. 이 도구는 아동용 Attention Network Test (Choi, 2014; Fan, McCandliss, Sommer, Raz, \& Posner, 2002)를 참고로 개발되었다. 이 연구에서 시각적 주의 과제는 컴퓨터 화면에 $4 \times 4$ 의 칸 중 + 표시가 임의로 5 개 제시될 때, $2 \times 2$ 로 + 표시 가 모이는 자극(표적)이 나타나면 유아가 가능한 빨리 스페이 스바를 누르고, 그 외의 자극(비표적)이 나타나면 유아가 아무 런 반응을 하지 않는 과제로 구성하였다. 청각적 주의 과제는 유아가 컴퓨터 화면(빈 화면)을 응시하다가 ‘뚜-뚜-' 소리(표 적)가 들리면 유아가 가능한 빨리 스페이스바를 누르고, '뚜-' 소리(비표적)가 들리면 유아가 아무런 반응을 하지 않는 과제 로 구성하였다. 각 과제는 연습시행 3회와 본시행 20회(표적
자극 10 개, 비표적 자극 10 개)로 구성하였다. 유아의 응답은 E-prime 프로그램에 자동으로 기록되었으며, 유아의 반응 정 확률이 계산되어 통계 분석에 이용되었다. 주의 측정 도구는 유아교육 전문가 2 인에 의해 타당도를 검증받았다. 유아교육 전문가들의 검토 의견을 바탕으로, 주의 과제의 난이도, 사용 자극, 시행 횟수 등이 유아의 수준에 적절함을 확인하였다. 이 렇게 제작된 주의 측정 도구는 예비조사를 통해 연령 적합성 을 한 번 더 확인한 후 본 조사에 이용하였다.

\section{연구절차}

\section{예비조사}

이 연구에서는 제작한 교수자료와 학습효과 측정 도구, 작업 기억 및 주의 측정 도구의 적절성과 전반적인 조사 과정의 적 절성을 확인하기 위해 예비조사를 실시하였다. 예비조사는 본 조사에 참여하지 않은 만 5세 유아 6명(연구 집단별 2명)을 대 상으로 하였다. 예비조사 결과, 각 교수자료와 학습효과 측정 도구는 만 5 세 유아에게 적절한 수준으로 확인되었다. 다만, 예비조사 후 연구자는 학습효과 측정 문항 중 몇몇 표현을 아 이들이 더 쉽게 이해할 수 있는 표현으로 수정, 보완하였다. 이 연구에서 구성한 스크립트의 내용은 아이들이 거의 처음 접하 는 것이었으며(질문을 통해 확인), 유아의 총 학습 활동과 질 문지 응답 시간은 20 분 정도로 적합하였다. 또한, 작업기억 및 주의 측정 도구의 과제는 만 5세 유아의 인지적 발달 수준에 적합한 것을 확인하였고, 이러한 과제들에 대한 참여 시간도 20 분 정도로 적절하였다.

\section{본조사}

이 연구는 기관 생명연구윤리위원회의 승인을 받아 실시되었 다. 연구자는 유아의 부모에게 연구의 목적 및 방법, 보상 등을 상세하게 전달하고 부모가 유아의 연구 참여에 동의한 경우 그 유아를 연구 대상자로 선정하였다. 본조사는 2020년 9월 3 일부터 2021년 2월 15일까지 서울, 경기, 인천, 대전 지역의 유 치원에 다니는 만 5세 유아 86명을 대상으로 하였다.

본조사에서 연구 참여 유아들은 난수표를 이용하여 3 개의 연구 집단 중 한 집단에 무선 할당되었고, 개별적으로 연구에 참여하였다. 본조사는 연구자와 연구 보조자 1 인이 함께 진행 하였다. 먼저, 연구자는 유아를 유치원의 조용한 공간으로 안 내하고, 간단한 대화를 통해 라포를 형성하였다. 조사가 시작 
되면 연구자는 유아에게 일대일로 참여 조건에 맞는 교수자 료 슬라이드를 제시하고, 유아에게 재미있는 자연현상 이야기 를 듣고 퀴즈를 맞히는 게임을 할 것이라고 설명하였다. 그 다 음, 유아에게 천둥과 번개, 하늘 위의 무지개 교수자료 슬라이 드를 보여주고, 각각의 교수자료를 본 직후 유아의 학습효과 를 측정하였다. 교수자료 주제의 순서는 유아별로 임의로 제 시하여 순서효과를 통제하였다. 유아의 작업기억과 주의 측정 은 유아의 주의집중 시간을 고려하여, 학습 활동 후 다른 시간 (오후 또는 다른 날)에 실시하였다. 연구자는 유아에게 작업기 억 과제와 주의 과제의 수행 방법을 자세히 설명하였고, 유아 는 이에 따라 과제를 수행하였다. 유아의 응답은 기록지 또는 E-prime 프로그램에 기록되었다. 이 연구에서 유아들은 2회에 걸쳐(학습 활동, 인지능력 검사) 20 분씩 조사에 참여하였으며, 총 연구 참여 시간은 40 분 정도였다. 이 연구에서 연구자는 유 아가 과제에 참여하기를 원하지 않는 경우 언제든지 그만둘 수 있음을 유아에게 전달하고 그와 같은 지침에 따라 조사를 진행하였다. 그렇지만 실제 조사에서 유아가 과제 참여를 원 하지 않거나 어려워하여 조사가 중단된 경우는 없었다.

\section{자료분석}

수집된 데이터는 SPSS 20 (IBM Co., Armonk, NY) 프로그램 을 이용하여 분석되었다. 먼저 전반적인 유아의 응답 경향성 을 확인하기 위해 평균, 표준편차 등의 기초통계분석이 실시 되었다. 다음으로, 교수자료의 정보제시 방식과 유아의 청각 및 시각 작업기억 용량에 따라 유아의 학습효과가 달라지는 지 확인하기 위해, 일원변량분석, 이원변량분석, 독립표본 $t$ 검정 등이 실시되었다. 교수자료의 정보제시 방식에 따른 학 습효과 분석 시에는, 정보제시 방식을 독립변인으로, 유아의 인지능력(작업기억, 주의)을 공변인으로 투입한 일원변량분 석을 실시하여 집단별 유아의 인지능력을 통제하였다. 또한, 유아의 청각 및 시각 작업기억 용량에 따른 학습효과 분석 시 에는, 청각 작업기억 용량이 큰 집단(상위 $30 \%$ )과 작은 집단 (하위 $30 \%$ ), 시각 작업기억 용량이 큰 집단(상위 $30 \%$ )과 작 은 집단(하위 $30 \%$ )의 학습효과를 독립표본 $t$-검정을 통해 비 교 분석하였다. 이 연구에서는 Yoo와 $\operatorname{Lim}$ (2015), Lim과 Choi (2017)의 연구에 근거하여 작업기억의 집단 구분 준거로 상하 위 $30 \%$ 기준을 설정하였다. 이는 중앙값을 기준으로 한 상하 위 집단 구분보다 집단 간 비교 시 통계적 검정력(power)을 높 일 수 있다. 마지막으로, 교수자료의 청각, 시각 정보제시 방식 과 유아의 청각, 시각 작업기억 용량 간의 상호작용 효과 분석
시에는, 정보제시 방식과 청각(시각) 작업기억 용량을 독립변 인으로 투입한 이원변량분석을 실시하였고 변인 간의 상호작 용 효과를 더 구체적으로 살펴보기 위해 하위 조건별로 단순 주효과 분석을 실시하였다.

\section{Results}

\section{교수자료의 정보제시 방식에 따른 유아의 학 습효과}

연구문제 1 에 대한 분석에 앞서, 연구 참여 유아의 주의 능력 및 작업기억 용량을 살펴보면 Table 4와 같다. 유아의 주의과 제 수행의 정답률은 청각과 시각 과제에서 각각 .91 $(S D=.10)$ $.94(S D=.11)$ 로 나타났고, 집단별로 조금씩 달라졌다. 유아의 작업기억 용량은 청각과 시각 과제에서 각각 $3.67(S D=.82)$, $3.24(S D=.82)$ 로 나타났으며, 이 또한 집단별로 조금씩 달라 졌다. Table 4는 참여 유아들의 주의 능력 및 작업기억 용량에 대한 전반적인 수준과 집단별, 과제별 차이에 대한 기본 정보 를 제시해준다.

다음으로, 교수자료의 정보제시 방식에 따라 유아의 학습 효과가 유의한 차이를 보이는지 확인하기 위해, 문항 유형별 로 교수자료의 정보제시 방식을 독립변인으로, 유아의 작업기 억, 주의 점수를 공변인으로 투입한 One-way ANOVA 분석을 실시한 결과는 Table 5 와 같다.

그 결과, 교수자료의 정보제시 방식에 따른 유아의 학습효 과 차이는 사실 문항 $(F=11.224, p<.001)$, 추론 문항 $(F=7.220$, $p<.01)$, 전체 문항 $(F=12.673, p<.001)$ 모두에서 유의하게 나타났다. 이를 더 구체적으로 살펴보기 위해 공변량분석의 $\mathrm{LSD}$ 사후검증을 실시한 결과, 유아의 사실 문항 점수는 청각 먼저 제시 조건 $(M=5.92, S D=2.15)$ 과 시각먼저 제시 조건 $(M=5.90, S D=2.15)$ 보다 청각, 시각정보 동시 제시 조건 $(M$ $=8.16, S D=2.11)$ 에서 더 높게 나타났고, 유아의 추론 문항 점 수도 청각먼저 제시 조건 $(M=3.39, S D=1.83)$ 과 시각먼저 제 시 조건 $(M=3.15, S D=1.82)$ 보다 청각, 시각정보 동시 제시 조건 $(M=4.78, S D=1.79)$ 에서 더 높게 나타났다. 마지막으로, 유아의 전체 문항 점수도 청각먼저 제시 조건 $(M=9.31, S D=$ $3.40)$ 과 시각먼저 제시 조건 $(M=9.05, S D=3.39)$ 에 비해 청각, 시각정보 동시 제시 조건 $(M=12.94, S D=3.33)$ 에서 더 높게 나타났다. 이는 청각 정보(언어적 설명)와 시각 정보(그림)를 동시에 제시하는 방식이 이들을 각각 순차적으로 하나씩 제시 
Table 4

Attention and Working Memory Capacity of Young Children by Research Groups

\begin{tabular}{llllll}
\hline & & Group 1 & Group 2 & Group 3 & Total \\
& & $M(S D)$ & $M(S D)$ & $M(S D)$ & $M(S D)$ \\
\hline Attention & Auditory & $.93(.10)$ & $.91(.12)$ & $.91(.10)$ & $.91(.10)$ \\
& Visual & $.95(.06)$ & $.91(.17)$ & $.95(.06)$ & $.94(.11)$ \\
& Total & $.94(.06)$ & $.91(.13)$ & $.93(.07)$ & $.93(.09)$ \\
\hline Working memory capacity & Auditory & $3.77(.83)$ & $3.33(.83)$ & $3.93(.68)$ & $3.67(.82)$ \\
& Visual & $3.21(.87)$ & $3.06(.97)$ & $3.44(.54)$ & $3.24(.82)$ \\
& Total & $3.49(.69)$ & $3.20(.78)$ & $3.69(.45)$ & $3.45(.68)$ \\
\hline
\end{tabular}

Table 5

Learning Effectiveness of Young Children According to the Teaching Material Presentation Methods

\begin{tabular}{|c|c|c|c|c|}
\hline \multirow{3}{*}{ Items } & \multicolumn{3}{|c|}{ Teaching material presentation } & \multirow[b]{3}{*}{$F$} \\
\hline & \multicolumn{2}{|c|}{ Sequential presentation } & \multirow[b]{2}{*}{$\begin{array}{c}\text { Simultaneous presentation } \\
\qquad M(S D)\end{array}$} & \\
\hline & $\begin{array}{c}\text { Auditory-first } \\
M(S D)\end{array}$ & $\begin{array}{c}\text { Visual-first } \\
M(S D)\end{array}$ & & \\
\hline Fact & $5.92(2.15) \mathrm{a}$ & $5.90(2.15) \mathrm{a}$ & $8.16(2.11) \mathrm{b}$ & $11.224^{* * *}$ \\
\hline Inference & $3.39(1.83) \mathrm{a}$ & $3.15(1.82) \mathrm{a}$ & $4.78(1.79) \mathrm{b}$ & $7.220^{* *}$ \\
\hline Total & $9.31(3.40) \mathrm{a}$ & $9.05(3.39) \mathrm{a}$ & $12.94(3.33) \mathrm{b}$ & $12.673^{* * *}$ \\
\hline
\end{tabular}

Note. Children's working memory and attention of group $1(\mathrm{n}=31)$, group $2(\mathrm{n}=28)$, group $3(\mathrm{n}=27)$ are controlled. LSD test: a low, b high. ${ }^{* *} p<.01 .{ }^{* * *} p<.001$.

Table 6

Bottom, Mid, Top Group’s Working Memory Capacity of Young Children in Each Research Group

\begin{tabular}{|c|c|c|c|c|c|}
\hline \multicolumn{2}{|c|}{ Working memory capacity } & $\begin{array}{l}\text { Bottom } 30 \% \\
\quad M(S D)\end{array}$ & $\begin{array}{c}\text { Mid } 40 \% \\
M(S D)\end{array}$ & $\begin{array}{l}\text { Top } 30 \% \\
M(S D)\end{array}$ & $\begin{array}{c}\text { All } \\
M(S D)\end{array}$ \\
\hline \multirow[t]{2}{*}{ Group 1} & Auditory & $2.78(.52)$ & $3.88(.28)$ & $4.58(.57)$ & $3.77(.83)$ \\
\hline & Total & $2.67(.27)$ & $3.50(.24)$ & $4.29(.40)$ & $3.49(.69)$ \\
\hline Group 2 & Auditory & $2.33(.40)$ & $3.48(.42)$ & $4.17(.25)$ & $3.33(.83)$ \\
\hline \multirow[t]{3}{*}{ Group 3} & Auditory & $3.28(.44)$ & $3.86(.13)$ & $4.64(.47)$ & $3.93(.68)$ \\
\hline & Visual & $2.81(.33)$ & $3.56(.11)$ & $3.97(.20)$ & $3.44(.54)$ \\
\hline & Total & $3.25(.27)$ & $3.65(.12)$ & $4.15(.32)$ & $3.69(.45)$ \\
\hline All & Auditory & $2.80(.59)$ & $3.75(.35)$ & $4.46(.48)$ & $3.67(.82)$ \\
\hline
\end{tabular}

하는 방법보다 유아의 학습에 효과적이며, 순차 제시 조건에 서 청각 정보(언어적 설명)와 시각 정보의 제시 순서는 유아의 학습효과에 영향을 미치지 않음을 보여준다.
유아의 청각, 시각 작업기억 용량에 따른 학 습효과

연구문제 2에 대한 분석에 앞서, 연구에 참여한 집단 $1,2,3$ 유 
Table 7

Learning Effectiveness of Young Children According to Their Auditory and Visual Working Memory Capacity

\begin{tabular}{|c|c|c|c|c|c|c|}
\hline \multirow[b]{2}{*}{ Items } & \multicolumn{2}{|c|}{ Auditory working memory capacity } & \multirow[b]{2}{*}{$t$} & \multicolumn{2}{|c|}{ Visual working memory capacity } & \multirow[b]{2}{*}{$t$} \\
\hline & $\begin{array}{c}\text { Bottom } 30 \% \\
M(S D)\end{array}$ & $\begin{array}{c}\text { Top 30\% } \\
M(S D)\end{array}$ & & $\begin{array}{c}\text { Bottom } 30 \% \\
M(S D)\end{array}$ & $\begin{array}{l}\text { Top } 30 \% \\
M(S D)\end{array}$ & \\
\hline Fact & $4.94(2.24)$ & $6.25(2.11)$ & -1.799 & $4.97(2.51)$ & $6.42(2.19)$ & -1.841 \\
\hline Inference & $2.44(1.55)$ & $3.75(2.17)$ & $-2.076^{*}$ & $2.25(1.42)$ & $3.97(2.01)$ & $-2.970^{* *}$ \\
\hline Total & $7.39(3.54)$ & $10.00(3.79)$ & $-2.136^{*}$ & $7.22(3.53)$ & $10.39(3.45)$ & $-2.723^{*}$ \\
\hline
\end{tabular}

${ }^{*} p<.05 .{ }^{* *} p<.01$.

아들의 작업기억 용량을 상중하 집단별로 분석하여 살펴본 결 과는 Table 6과 같다. 전체 유아의 청각 작업기억 용량은 하위 $30 \%$ 가 $2.80(S D=.59)$, 중위 $40 \%$ 가 $3.75(S D=.35)$, 상위 $30 \%$ 가 $4.46(S D=.48)$ 으로, 하위 $30 \%$ 와 상위 $30 \%$ 간에 상당한 차 이(1.66)를 보였다. 또한, 전체 유아의 시각 작업기억 용량도 하위 $30 \%$ 가 $2.32(S D=.51)$, 중위 $40 \%$ 가 $3.25(S D=.35)$, 상 위 $30 \%$ 가 $4.13(S D=.33)$ 으로, 상하위 그룹 간에 상당한 차이 (1.81)를 보였다. 연구 집단별로 유아의 작업기억 용량이 조금 씩 달라지기는 하였지만, 하위 30\%와 상위 30\% 간에 상당한 차이가 나타나는 것은 유사하였다. Table 6의 분석 결과는 유아 의 작업기억 용량의 분포를 집단별, 감각양식별로 제시해준다.

다음으로, 유아의 청각, 시각 작업기억 용량에 따라 유아의 학습효과가 달라지는지 살펴보기 위해, 청각, 시각 작업기억 의 하위 $30 \%$ 집단과 상위 $30 \%$ 집단의 학습효과 차이를 $t$-분석 을 통해 확인한 결과는 Table 7과 같다.

분석 결과, 청각 작업기억 용량의 하위 $30 \%$ 집단과 상위 $30 \%$ 집단의 학습효과 차이는 추론 문항 $(t=-2.076, p<.05)$ 과 전체 문항 $(t=-2.136, p<.05)$ 에서 유의하게 나타났다. 구체적 으로, 유아의 추론 문항 점수는 청각 작업기억 상위 $30 \%$ 집단 $(M=3.75, S D=2.17)$ 이 하위 $30 \%$ 집단 $(M=2.44, S D=1.55)$ 에 비해 더 높았고, 전체 문항 점수도 청각 작업기억 상위 $30 \%$ 집단 $(M=10.00, S D=3.79)$ 이 하위 $30 \%$ 집단 $(M=7.39, S D=$ 3.54)보다 더 높게 나타났다. 즉, 청각 작업기억 용량이 큰 집 단이 작은 집단에 비해 추론 점수와 전체 문항의 점수가 높게 나타난 것이다. 이는 학습 내용을 충분하게 이해하여 다른 상 황에 적용하기 위해서는 청각적(언어적) 자극을 민감하게 수 용, 인식하며, 처리하고 해석하는 기능들이 필요함을 시사해 준다.

또한, 시각 작업기억 용량의 하위 $30 \%$ 집단과 상위 $30 \%$ 집 단의 학습효과 차이도 추론 문항 $(t=-2.970, p<.01)$ 과 전체 문 항 $(t=-2.723, p<.05)$ 에서 유의하게 나타났다. 구체적으로,
유아의 추론 문항 점수는 시각 작업기억 상위 $30 \%$ 집단 $(M=$ $3.97, S D=2.01)$ 이 하위 $30 \%$ 집단 $(M=2.25, S D=1.42)$ 에 비 해 더 높게 나타났고, 전체 문항 점수도 시각 작업기억 상위 $30 \%$ 집단 $(M=10.39, S D=3.45)$ 이 하위 $30 \%$ 집단 $(M=7.22$, $S D=3.53)$ 보다 더 높게 나타났다. 이러한 결과는 학습 장면에 서 학습의 매체로 시각자료가 이용될 때, 시각 작업기억 용량 이 큰 유아들이 작은 유아들에 비해 시각 정보처리를 한 번에 많이, 더 빠르고 효율적으로 할 수 있어 학습 내용을 더 깊이 있게 잘 이해하는 데 유리할 수 있음을 보여주는 결과라 할 수 있다.

\section{교수자료의 청각, 시각 정보제시 방식과 유아 의 청각, 시각 작업기억 용량 간의 상호작용}

우선, 교수자료의 청각, 시각 정보제시 방식(청각먼저 제시, 시각먼저 제시)과 유아의 청각 작업기억 용량이 유아의 학습 효과에 미치는 영향에서 두 변인 간 상호작용 효과가 나타나 는지 확인하기 위하여, 교수자료의 청각, 시각 정보제시 방식 과 청각 작업기억 용량을 변인으로 투입한 2-way ANOVA 분 석을 실시한 결과는 Table 8과 같다.

분석 결과, 청각 작업기억 용량의 주효과 $(F=5.497, p<$ $.05)$, 청각, 시각 정보제시 방식과 청각 작업기억 용량 간의 상 호작용 효과 $(F=8.662, p<.01)$ 가 유의하게 나타났다. 청각 작 업기억 용량의 주효과는 앞서 살펴본 결과와 일치하였고, 여 기에서는 청각, 시각 정보제시 방식과 청각 작업기억 용량 간 의 상호작용 효과를 더 구체적으로 살펴보기 위해 단순주효과 분석을 실시하였다.

이를 위해, 정보제시 순서 조건별로 유아의 청각 작업기억 용량의 하위 $30 \%$ 집단과 상위 $30 \%$ 집단의 학습효과 차이를 독립표본 $t$-검정을 통해 분석하였다(Table 9, Figure 1). 그 결과, 청각먼저 제시 조건에서는 청각 작업기억 용량의 상위 $30 \%$ 와 
Table 8

Learning Effectiveness of Young Children According to the Sequence of Teaching Material Presentation and Children's Auditory Working Memory Capacity

\begin{tabular}{lcccc}
\hline Factor & $S S$ & $d f$ & $M S$ & \\
\hline Sequence of teaching material presentation (A) & 3.36 & 1 & 3.36 & .301 \\
Auditory working memory capacity (B) & 61.36 & 1 & 61.36 & $5.497^{*}$ \\
A $\times$ B & 96.69 & 1 & 96.69 & $8.662^{* *}$ \\
Error & 357.22 & 32 & 11.16 &
\end{tabular}

${ }^{*} p<.05 .{ }^{* *} p<.01$.

Table 9

Learning Effectiveness of Young Children According to their Auditory Working Memory Capacity by Condition of the Sequence of Teaching Material Presentation

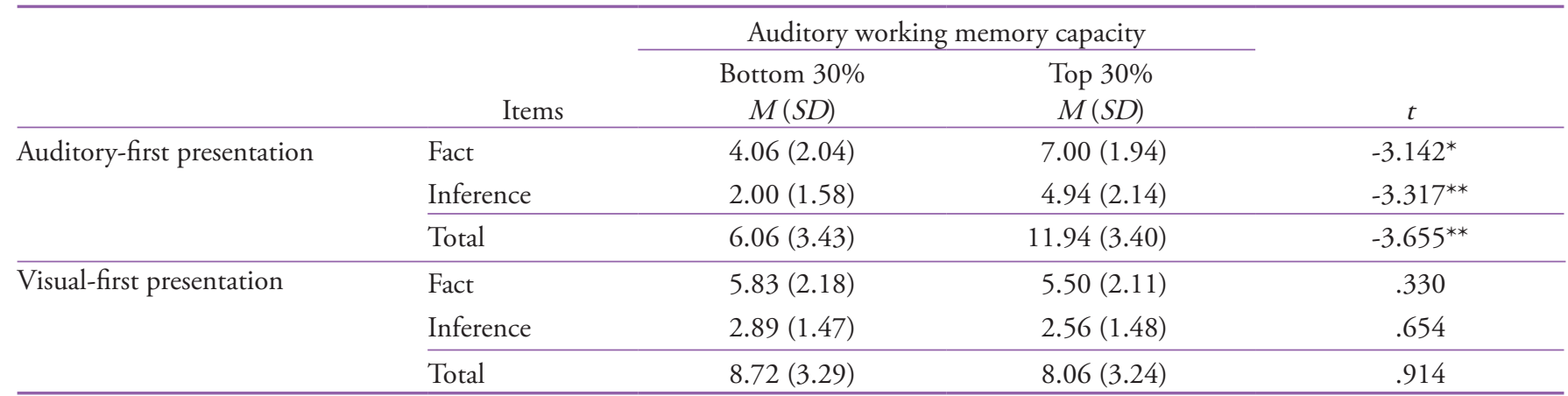

${ }^{*} p<.05 .{ }^{* *} p<.01$.

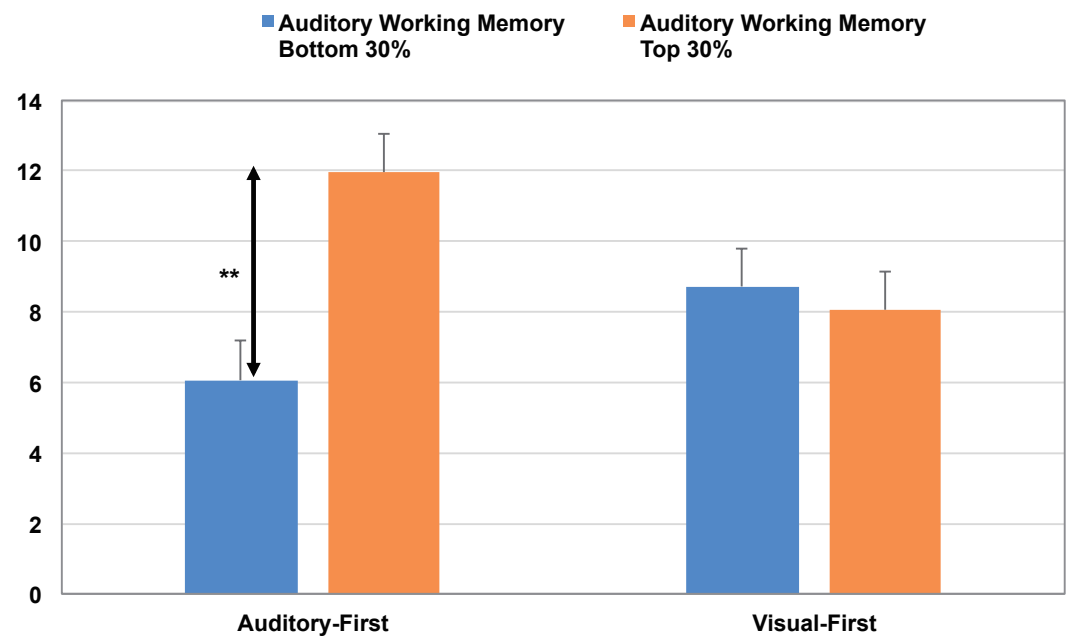

Figure 1. Learning effectiveness of young children according to their auditory working memory capacity by sequence of teaching material presentation (Error bars represent standard errors).

하위 $30 \%$ 유아들의 학습효과가 사실 문항 $(t=-3.142, p<.05)$, 추론 문항 $(t=-3.317, p<.01)$, 전체 문항 $(t=-3.655, p<.01)$ 모 두에서 유의한 차이를 보였지만, 시각먼저 제시 조건에서는 유아의 청각 작업기억 용량의 상위 $30 \%$ 와 하위 $30 \%$ 유아들 의 학습효과가 모든 유형의 문항에서 유의한 차이를 보이지 않았다. 구체적으로, 청각먼저 제시 조건에서 사실 문항 점수
는 청각 작업기억 상위 $30 \%$ 집단 $(M=7.00, S D=1.94)$ 이 하위 $30 \%$ 집단 $(M=4.06, S D=2.04)$ 에 비해 높았고, 추론 문항 점 수도 청각 작업기억 상위 $30 \%$ 집단 $(M=4.94, S D=2.14)$ 이 하 위 $30 \%$ 집단 $(M=2.00, S D=1.58)$ 에 비해 더 높았다. 또한, 전 체 문항 점수도 청각 작업기억 상위 $30 \%$ 집단과 하위 $30 \%$ 집 단이 각각 $11.94(S D=3.40), 6.06(S D=3.43)$ 으로 청각 작업기 
Table 10

Learning Effectiveness of Young Children According to the Sequence of Teaching Material Presentation and Children's Visual Working Memory Capacity

\begin{tabular}{lrrrr}
\hline \multicolumn{1}{c}{ Factor } & \multicolumn{1}{c}{ SS } & df & \multicolumn{1}{c}{ MS } \\
\hline Sequence of teaching material presentation (A) & .44 & 1 & .44 & .035 \\
Visual working memory capacity (B) & 90.25 & 1 & 90.25 & $7.032^{*}$ \\
A $\times$ B & 2.78 & 1 & 2.78 & .216 \\
Error & 800.78 & 32 & 8.17 & \\
\hline
\end{tabular}

${ }^{*} p<.05$.

Table 11

Learning Effectiveness of Young Children According to their Visual Working Memory Capacity by Condition of the Sequence of Teaching Material Presentation

\begin{tabular}{|c|c|c|c|c|}
\hline & \multirow[b]{3}{*}{ Items } & \multicolumn{2}{|c|}{ Visual working memory capacity } & \multirow[b]{3}{*}{$t$} \\
\hline & & Bottom 30\% & Top 30\% & \\
\hline & & $M(S D)$ & $M(S D)$ & \\
\hline \multirow{2}{*}{ Auditory-first presentation } & Inference & $2.06(1.55)$ & $3.72(2.03)$ & -1.956 \\
\hline & Total & $7.39(4.04)$ & $10.00(3.96)$ & -1.384 \\
\hline Visual-first presentation & Total & $7.06(3.17)$ & $10.78(3.04)$ & $-2.543^{*}$ \\
\hline
\end{tabular}

${ }^{*} p<.05$.

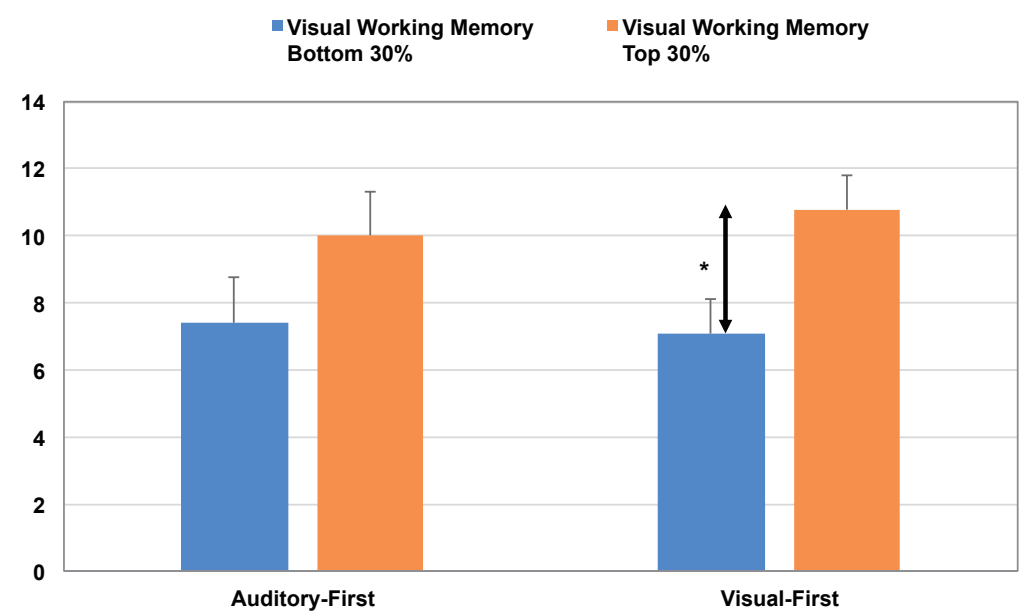

Figure 2. Learning effectiveness of young children according to their visual working memory capacity by sequence of teaching material presentation (Error bars represent standard errors).

억 상위 $30 \%$ 인 유아들이 더 높게 나타났다.

다음으로, 교수자료의 청각, 시각 정보제시 방식(청각먼 저 제시, 시각먼저 제시)과 유아의 시각 작업기억 용량이 유 아의 학습효과에 미치는 영향에서 두 변인 간의 상호작용 효 과가 나타나는지 확인하기 위하여, 교수자료의 청각, 시각 정 보제시 방식과 시각 작업기억 용량을 변인으로 투입한 2-way
ANOVA 분석을 실시하였다.

그 결과, Table 10 과 같이 시각 작업기억 용량의 주효과 $(\mathrm{F}=$ 7.032, $p$ <.05)만 유의하게 나타났고, 교수자료의 청각, 시각 정보제시 방식과 시각 작업기억 용량 간의 상호작용 효과는 유의하게 나타나지 않았다. 여기에서는 앞서 확인한 시각 작 업기억 용량의 주효과를 재확인할 수 있었지만, 두 변인 간의 
상호작용 효과는 확인할 수 없었다. 그렇지만, 선행연구에서 학습자가 잘 처리할 수 있는 감각양식의 정보를 학습자에게 먼저 제시할 때 학습효과가 높아질 수 있음을 보인 선행연구 를 바탕으로(Do \& Hwang, 2006), 추가적인 단순주효과 분석 을 더 실시해보았다. 이를 위해 정보제시 순서 조건별로 유아 의 시각 작업기억 용량이 큰 집단(상위 $30 \%$ )과 작은 집단(하 위 $30 \%)$ 을 나누어 두 하위 집단 간 학습효과의 차이를 독립표 본 $t$-검정을 통해 분석한 결과는 Table 11과 같다.

그 결과, 청각먼저 제시 조건에서는 시각 작업기억 용량의 상위 $30 \%$ 와 하위 $30 \%$ 유아들의 학습효과가 사실, 추론, 전체 문항 모두에서 유의한 차이를 보이지 않았지만, 시각먼저 제 시 조건에서는 시각 작업기억 용량의 상위 $30 \%$ 와 하위 $30 \%$ 유아들의 학습효과가 추론 문항 $(t=-2.160, p<.05)$ 과 전체 문 항 $(t=-2.543, p<.05)$ 에서 유의한 차이를 보였다. 구체적으로, 시각먼저 제시 조건에서, 유아의 추론 문항 점수는 시각 작업 기억 상위 $30 \%$ 집단 $(M=4.22, S D=2.08)$ 이 하위 $30 \%$ 집단 $(M$ $=2.44, S D=1.33)$ 에 비해 더 높았고, 전체 문항 점수도 시각 작 업기억 상위 $30 \%$ 집단 $(M=10.78, S D=3.04)$ 이 하위 $30 \%$ 집 단 $(M=7.06, S D=3.17)$ 보다 더 높게 나타났다(Figure 2).

이와 같은 결과들은 청각 정보를 시각 정보보다 더 먼저 제 시하는 경우, 청각 작업기억 용량이 큰 유아들이 전달 내용을 더 잘 기억하고, 통합적으로 잘 이해하며, 시각 정보를 청각 정 보보다 더 먼저 제시하는 경우에는, 반대로 시각 작업기억 용 량이 큰 유아들이 전달 내용을 잘 이해하고 통합할 수 있다는 것을 보여준다. 이러한 결과는 유아의 인지처리 시스템의 기 제, 정보처리 효율성이 학습효과에 미치는 영향 등과 관련하 여 더 논의될 수 있을 것이다.

\section{Discussion}

이 연구는 교수자료의 정보제시 방식과 유아의 청각, 시각 작 업기억 용량의 개인차가 유아의 학습효과에 미치는 영향을 살 펴, 개별 유아들에게 보다 효과적인 교수 방안에 대한 시사점 을 제공하는 것을 목적으로, 총 86명의 만 5 세 유아를 대상으 로 조사를 진행하였다. 분석 결과를 바탕으로 한 결론과 논의 점은 다음과 같다.

첫째, 교수자료의 정보제시 방식에 따라 유아의 학습효과 가 달라졌다. 즉, 유아에게 청각, 시각 정보를 순차적으로 각 각 제시할 때보다 동시에 제시할 때, 유아의 학습효과가 더 높 게 나타났다. 이러한 결과는 Mayer와 Anderson (1992)의 시간
인접의 원리, 정보의 이중 부호화 효과, 인간의 정보처리 시스 템의 기제 등과 관련하여 더 논의될 수 있을 것이다. 먼저, 이 는 학습자에게 정보를 전달할 때, 언어적 설명과 그림을 동시 에 제시하는 경우가 각각 따로 순차적으로 제시하는 경우보다 학습효과를 높일 수 있음을 제안한 Mayer와 Anderson (1992) 의 시간인접의 원리를 지지하며, 청각, 시각 정보의 이중 부 호화(dual encoding)가 학습효과를 높인다는 많은 선행연구의 결과들을 지지한다(Cuevas, 2016; Mayer \& Sims, 1994; Plass, Chun, Mayer, \& Leutner, 1998; Rohrer \& Pashler, 2012). 또한, 이러한 결과는 인간의 인지처리 시스템의 기제와도 관련하여 해석해볼 수 있다. 인간은 끊임없이 다양한 청각, 시각 정보들 을 수용하여 감각양식별로 분리된 각각의 처리 공간(음운론 적 회로, 시공간잡기장)에서 실시간으로 처리하며, 이렇게 처 리된 정보들을 장기기억의 정보들과 함께 통합하게 된다(Park \& Kwon, 2010; Mayer \& Moreno, 2002, 2003). 따라서, 어떤 정 보가 유아에게 청각적, 시각적으로 동시에 제시된다면, 정보 의 동시적 수용과 처리, 통합이 빠르고 효율적으로 이루어질 수 있지만, 시차를 두고 제시된다면 이러한 빠르고 효율적인 정보처리를 기대할 수 없을 것이다. 즉, 이러한 결과는 청각 정 보와 시각 정보를 순차적으로 제시하는 것이 유아에게 정보처 리의 시간을 충분하게 확보하게 하여 유아의 인지부하를 낮춰 주는 것이 아니라, 오히려 이러한 제시 시차가 정보의 즉시적 이중 처리와 통합, 빠른 정보처리를 방해하여 학습 수행의 저 하를 야기할 수 있음을 시사해준다. 이와 같이 청각, 시각 정보 들의 동시 제시는 유아의 정보처리 효율성을 높이고, 정보의 깊이 있는 처리 및 통합적 처리를 도와 유아의 학습효과를 높 이는 방법으로 제안될 수 있을 것이다.

그러나, 청각 정보와 시각 정보를 순차적으로 제시할 때, 그 제시 순서에 따라서는 유아의 학습효과가 달라지지 않았다. 지금까지 유아기에 특정 유형의 작업기억이 발달 우위에 있 다고 밝히거나 보고된 경우는 찾아보기 어려운데, 이 연구의 결과도 그 맥을 같이 한다. 즉, 이러한 결과를 통해 청각적 처 리 $\rightarrow$ 시각적 처리 $\rightarrow$ 통합이나 시각적 처리 $\rightarrow$ 청각적 처리 $\rightarrow$ 통합의 과정은 정보의 종합적 처리 속도나 깊이의 측면에 서 크게 차이를 보이지 않음을 알 수 있다. 따라서, 이러한 청 각, 시각 정보제시 순서에 따른 정보처리 영향은 유아들의 작 업기억 특성(청각, 시각 작업기억 용량)에 따른 양식별 정보처 리 효율성의 개인차와 관련하여 뒤에서 더 논의될 수 있을 것 이다.

둘째, 유아의 청각, 시각 작업기억 용량에 따라 유아의 학습 효과가 달라졌다. 청각 작업기억 용량이 큰 집단이 작은 집단 
에 비해 학습효과가 높고, 시각 작업기억 용량이 큰 집단이 작 은 집단에 비해 학습효과가 높게 나타났다. 이와 같은 결과는 멀티미디어 학습 시(외국어 학습 시 시각적 주석이 제시됨) 언 어적 능력이 높은 집단이 낮은 집단에 비해, 시공간적 능력이 높은 집단이 낮은 집단에 비해 학습 점수가 더 높았다는 선행 연구(Plass, Chun, Mayer, \& Leutner, 2003), 시청각 정보가 동시 에 제공되는 멀티미디어 학습이 시공간 작업기억 용량이 작은 학습자들보다 큰 학습자들에게 더 도움이 되었다는 선행연구 (Mayer \& Sims, 1994) 등의 결과를 지지한다. 이 연구에서 유 아의 청각 작업기억 용량이 크거나 또는 시각 작업기억 용량 이 클 때, 유아의 학습효과가 높게 나타난 것은 이 연구의 학 습 활동이 청각 정보(언어적 설명)와 시각 정보(시각자료)를 모두 활용하여 이루어졌다는 점과 관련하여 해석해볼 수 있을 것이다. 즉, 이 연구에서 청각적 신호(언어적 자극)는 학습 내 용을 주요하게 전달하는 매개물이 될 수 있는데, 청각 작업기 억 용량이 큰 유아들은 이러한 청각적 신호를 민감하게 인식 하고, 처리하고, 해석할 수 있기 때문에, 전체 학습 내용을 더 잘 기억하고 통합적으로 잘 이해할 수 있을 것이다. 뿐만 아니 라, 이 연구에서 제시된 시각자료는 학습 내용을 잘 담고 있는 중요한 보조 자료라 할 수 있다. 그래서 이러한 시각적 자극을 민감하게 수용하고, 인식 및 처리하는 능력이 클수록 학습 내 용을 더 정확하고 포괄적으로 이해할 수 있을 것이다. 따라서, 이 연구의 결과는 유아가 청각 및 시각 정보를 모두 활용하여 학습을 할 때, 청각 작업기억 용량 또는 시각 작업기억 용량 중 어느 쪽이라도 높다면 그것이 학습효과를 높이는데 긍정적 영 향을 미칠 수 있음을 시사해준다.

셋째, 청각 작업기억 용량이 큰 유아에게는 청각 정보를 시 각 정보보다 먼저 제시하는 방법이, 시각 작업기억 용량이 큰 유아에게는 시각 정보를 청각 정보보다 먼저 제시하는 방법이 유아의 학습효과를 높였다. 이러한 결과는 학습자의 학습 양 식이나 인지 양식에 맞게 교수자료가 제시될 때(감각정보 유 형, 제시 순서 등), 정보가 효율적으로 처리되고, 학습자의 학 습효과가 높아진다고 제안한 선행연구들(Do \& Hwang, 2006; E.-A. Kim, 2011; Plass et al., 1998; Riding \& Ashmore, 1980; Riding \& Rayner, 1998; Thomas \& McKay, 2010)과 맥을 같이 한다. Plass 등(1998)의 연구에서는 외국어 학습 시 학습자들이 선호하는 양식으로 학습 정보를 제공할 때(이야기의 키워드 를 텍스트, 그림 등으로 제시) 학습의 효과가 높았다. 특히, Do 와 Hwang (2006)의 연구는 학습자들에게 언어 정보를 먼저 제 시하는 경우와 시각 정보를 먼저 제시하는 경우, 학습자의 언 어, 시각 처리 능력에 따른 학습효과를 비교한 연구로 이 연구
와 연구 설계가 매우 유사하고, 결과도 이 연구의 결과와 일치 하였다. 이러한 결과는 청각 정보가 먼저 제시되고 시각 정보 가 뒤이어 제시될 때, 청각(언어) 정보를 잘 처리하는 유아들 은 먼저 제시되는 청각 정보들을 빠르고 효율적으로 처리하면 서 정보를 이해한 후, 바로 뒤이어 제시되는 시각자료의 정보 들을 바로 함께 통합함으로써, 전달 내용을 보다 정확하고 완 전하게 이해할 수 있는 것으로 해석해볼 수 있다. 반면, 청각 작업기억 용량이 작은 유아들은 먼저 제시되는 청각 정보를 빠르고 효율적으로 처리하지 못하여 정보처리 과정에서 인지 적 부하를 경험할 수 있으며, 이로 인해 뒤에 제시되는 시각 정 보의 빠른 통합과 이해, 정리도 어려움을 겪을 수 있는 것으로 보인다. 또한, 시각 정보가 청각 정보보다 먼저 제시되었을 때, 시각 작업기억 용량이 큰 유아들은 이를 빠르고 효율적으로 잘 처리하며 이러한 정보를 뒤에 이어서 제시되는 청각 정보 (언어적 설명)와 통합하여 전체적으로 높은 이해도를 나타내 는 것으로 보인다. 반면, 시각 작업기억 용량이 작은 유아들은 먼저 시각적으로 제시되는 정보를 충분히 잘 처리하고 유지하 지 못하여, 뒤이어 제시되는 언어적 설명과 통합하는 데 어려 움을 겪을 수 있을 것이다.

한편, 이 연구에서는 선행연구들을 바탕으로, 청각 정보가 먼저 제시되었을 때, 시각 작업기억 용량에 따른 학습효과의 차이가 거의 없을 것으로 예측하였다. 그러나 이 연구의 결과 에서는 청각 정보를 먼저 제시하는 조건에서도 시각 작업기억 용량이 큰(상위 $30 \%$ ) 유아들이 높은 학습효과를 보여주었다. 이러한 예상과 다른 결과는 이 조건(집단 2)에 참여한 유아들 의 양식별 작업기억 용량 분포와 관련하여 해석해볼 수 있을 것이다. 이 연구의 집단 2 에는 청각 작업기억과 시각 작업기억 용량이 모두 높은 유아들이 다수(9명 중 6명) 포함되어 있었 는데, 이 때문에 시각 작업기억 용량이 높은(청각도 함께 높은 경우 다수) 유아들도 청각 정보가 먼저 제시되었을 때 학습효 과가 높게 나타난 것으로 보인다. 따라서, 이러한 예측 밖의 결 과는 조사 집단의 크기가 충분히 크지 않아 나타난 결과로 볼 수 있을 것이다.

이 연구는 다음과 같은 학술적, 실용적 의의가 있다. 첫째, 이 연구는 그동안 유아교육에서 간과되어온 유아의 인지발달 의 개인차를 고려하여 유아를 위한 효과적인 교수 방안을 탐 색한 연구로, 유아를 대상으로 한 체계적인 교수공학적 연구 라는 점에서 의의가 있다. 이에 학습자로서의 유아, 교수자료, 교수방법 등을 동시에 고려하여 현장에서 유아의 학습을 도모 하고 그 효과를 높일 수 있는 유아교육에 관하여 시사점을 제 시할 수 있었다. 둘째, 이 연구는 그동안 유아교육에서 잘 다루 
어지지 않았던 유아의 시·청각 정보처리 능력과 그 개인차에 초점을 두어, 다양한 시·청각 매체 이용 교육에서 고려해야 할 교육자료 및 교수방법에 대한 시사점을 제시할 수 있었다는 점에서 의의가 있다. 즉, 시·청각 정보가 유아에게 어떻게 제 시되어야 하며, 유아의 시·청각 정보처리 특성(양식별 정보처 리 효율성)에 따라 맞춤형 교육자료는 어떻게 구성되는 것이 효과적인지, 유아를 위한 시·청각 자료의 활용에 대한 다양한 논의를 함께 이끌 수 있었다. 셋째, 이 연구가 밝힌 사실들은 유아의 인지발달과 교육 효과를 높이는 몇 가지 실용적인 제 안을 가능하게 한다는 점에서 실용적 의의가 있다. 이 연구의 결과들은 유아의 시·청각 자극의 처리 특성에 대한 기초 학문 적 정보뿐 아니라, 유아교육 현장에서 유아가 효율적으로 처 리할 수 있는 감각 정보에 따른 개별 유아 맞춤형 교육 방안에 대한 실용적인 시사점을 제공할 수 있었다.

이 연구의 몇몇 한계와 이를 해결하기 위한 후속연구, 교육 현장에서 유아의 학습효과를 높이기 위한 실용적인 교육 방 안 등을 제언하면 다음과 같다. 먼저, 앞서 결과 논의에서 언급 한 바와 같이, 이 연구에서는 조사한 집단별 표집 크기가 크지 않아 정밀한 결과 분석에 한계가 있었다. 특히, 이 연구의 연구 문제를 해결하기 위해, 연구자는 집단 2(청각먼저 제시)와 집 단 3(시각먼저 제시)의 유아들을 청각 작업기억 용량과 시각 작업기억 용량이 각각 상위 $30 \%$ 인 집단과 하위 $30 \%$ 인 집단 으로 나누어 제시 조건별로 학습효과를 비교하였는데, 이러한 비교 집단 중 청각, 시각 작업기억 용량이 동시에 높은 유아들 이 함께 포함되어 있어(집단 2: 9명 중 6명, 집단 3: 9명 중 2명), 보다 정확한 분석에 한계가 있었다. 따라서, 후속연구에서는 집단의 크기를 훨씬 크게 조사하고, 유아들의 청각, 시각 작업 기억 용량에 따라 더 세밀한 하위 조건들(상상, 상하, 하상, 하 하 등)을 만들어 이 연구에서 확인하고자 한 가설을 더욱 정밀 하게 검증할 필요가 있다. 또한, 이 연구에서는 교수자료의 청 각, 시각 정보제시 방식과 유아의 시각 작업기억 용량 간의 상 호작용을 분석하는 과정에서, 2-way ANOVA 분석에서 확인되 지 않았던 결과(상호작용 효과)가 단순주효과 분석에서는 확 인되었는데, 이러한 통계적 이슈도 조사 샘플수의 부족에서 야기된 문제로 보인다. 따라서, 이 연구의 결과 해석 시 보다 신중한 접근이 필요할 것이며, 충분한 샘플을 바탕으로 연구 가설을 더욱 명확하게 검증할 수 있는 후속연구가 진행되어야 할 것이다.

다음으로, 이 연구에서는 유아의 학습효과를 유아의 학습 내용에 대한 응답으로 측정하였고, 분석 결과를 선행연구들과 인지이론들에 기반을 두어 해석하였다. 이와 같은 조사도 의
미 있는 결과와 시사점을 도출할 수 있었지만, 만약 유아의 인 지 활동을 더 직접적으로 확인할 수 있는 신경생리학적 측정 을 함께 이용한다면, 연구 결과에 대한 해석에 더 다양하고 신 뢰로운 근거를 제공할 수 있을 것이다. 예를 들어, 뇌파 측정법 (EEG), 시선추적 방법(Eye tracking) 등을 함께 이용한다면, 각 연구 조건에서 유아의 학습 활동 시 인지부하나 주의집중 대 상, 주의집중 수준 등을 더 자세하게 확인할 수 있을 것이다. 따라서, 이와 같은 확장 연구를 진행한다면, 시·청각 정보제 시 방법을 고려한 다양한 교수안들의 이점이나 장단점을 보다 깊게 확인해볼 수 있을 것이다.

유아의 주의 능력은 이 연구에서 교수자료의 정보제시 방 식이 유아의 학습효과에 미치는 영향을 더욱 정확하게 측정하 기 위해 통제하였는데, 실제로 분석 결과 공변인으로 투입된 주의의 영향력이 유의한 것으로 확인되었다. 이는 유아의 주 의 능력이 학습효과에 영향을 미치는 중요한 인지 능력임을 보여줄 뿐 아니라, 유아의 주의 능력과 작업기억 용량이 각각 다른 영향력을 가지고 유아의 학습효과에 영향을 미칠 수 있 음을 보여준다. 즉, 이 연구에서는 유아의 주의 능력이 유아의 학습효과에 영향을 미치는 또 다른 핵심 변인이 될 수 있음을 확인하였다. 이와 관련하여 몇몇 선행연구들은 학습자의 주의 를 유도함으로써 학습효과를 높이는 몇 가지 교수 방안들을 제안하고 그 효과를 확인하였다(Amadieu, Mariné, \& Laimay, 2011; De Koning et al., 2010). 앞으로 후속 연구로 유아의 교 수-학습 과정에서 유아의 주의를 유도하여 학습효과를 높일 수 있는 다양한 방안들과 다양한 주의 측정 방법을 통한 그 효 과 검증이 제안될 수 있을 것이다.

마지막으로, 이 연구의 결론에 비춰보면, 현행 유아교육 현 장에서 활용하는 일반적인 교수 방안들은 모든 유아의 학습효 과를 높이기에는 한계가 있다. 이에 개별 유아의 정보처리 특 성에 따라 더 세심하게 개별화된 다양한 교수안들이 제안될 수 있을 것이다. 예를 들어, 유아교육 현장에서 교사들이 간단 한 검사를 통해 개별 유아가 더 효과적으로 처리하는 정보의 유형(시각 또는 청각)을 검사하거나, 자유놀이 시간 중 관찰 을 통해 유아가 선호하는 감각 정보의 유형을 확인하여(예를 들어, 시각 정보를 바탕으로 하는 퍼즐 놀이나 게임을 좋아하 는지, 언어(청각) 정보를 바탕으로 한 끝말잇기, 스무고개 등 의 게임을 좋아하는지 등을 확인), 유아교육 시에도 개별 유아 들이 선호하는 특정 감각 정보를 더 활발하게 다루는 몇몇 활 동안들을 준비할 수 있을 것이다. 그리고 이러한 활동들을 아 이들에게 제시하고 하고 싶은 활동을 고르도록 하여 그 활동 들을 소그룹으로 진행한다면, 같은 내용의 활동도 더 다양하 
게, 개별 유아의 정보처리 특성을 고려하여 진행할 수 있을 것 이다. 이러한 교수 방안은 아이들의 활동 참여도와 내용 이해 도, 학습효과 등을 높일 수 있는 효과적인 방안으로 제안될 수 있을 것이다. 이러한 방안은 프로젝트 접근법이나 레지오 에 밀리아 프로그램과 같은 다양한 프로그램에도 적용할 수 있을 것인데, 예를 들어, 아이들이 이러한 프로그램의 프로젝트를 진행할 때, 보다 다양한 시·청각 학습 재료들을 접하며 스스 로 선택하여 탐색하고(그림책, 소리, 실물 재료 등), 다양한 활 동들을 스스로 선택하여 진행해갈 수 있도록 한다면(그림 그 리기, 사진찍기, 책 만들기, 편지쓰기, 영상 만들기 등) 아이들 의 학습 주도성과 창의성을 높여줄 뿐 아니라 아이들의 학습 효과도 높일 수 있을 것이다. 이처럼 교육 활동에서 개별 유아 가 선호하는 감각 정보들을 유아의 학습에 활용할 수 있으며, 만약 애니메이션을 이용한 학습 활동을 준비할 시에는 시청각 정보의 동시 제시가 가장 학습효과를 높일 수 있으나, 정보가 순차적으로 제시되는 경우에는 그 순서 또한 아이들의 정보처 리 특성을 고려하여 구성될 수 있을 것이다.

다만, 이러한 유아 특성에 따른 개별화된 교수 방안을 실제 로 적용하는 데 있어서는 몇 가지 고려사항이 있을 것이다. 왜 냐하면, 학습자의 인지양식 또는 학습양식을 바탕으로 개별화 된 교수를 제공하는 방안은 여러 학자들에 의해 학습자의 개 인차를 고려한 가치 있는 교수법으로 인정받아 왔지만, 이에 대한 비판적 견해들도 존재하기 때문이다. 예를 들어, 인지양 식이나 학습양식 개념의 모호성, 측정의 타당성, 교사의 업무 부담, 실제 교육의 효과, 실증적 데이터 부족 등이 이러한 교수 법의 한계로 지적되어 왔다(Gudnason, 2017; Peterson, Rayner, \& Armstrong, 2009; Rayner, \& Riding, 1997). 이러한 비판적 견 해를 바탕으로 Gudnason (2017)은 전체 학습자를 대상으로 동 일하게 시청각 교육(dual-coding 교육)을 하는 것이 낫다는 주 장을 하기도 하였다. 즉, 모든 교육 장면에서 언어적, 시각적 자료를 모두 이용하여 학생들의 시청각 처리 경로를 발달시 키고, 교육자의 교수 효율성을 높이자는 주장이다. 이 연구에 서도 밝힌 바와 같이 청각, 시각 정보의 동시 제시를 통한 듀 얼 코딩 교육은 대부분의 교육 장면에서 교육 효과성을 높이 기 위해 사용할 수 있는 매우 강력한 교수 방법일 것이다. 특 히, 모든 감각 기관과 두뇌가 발달하고 있는 유아들에게는 더 욱 중요한 교수 방법이 될 수 있다. 그렇지만, 아이들의 학습 에 대한 흥미, 열정 등은 자신이 보다 선호하는 자극을 통해 더 유지되고 확대될 수 있을 것이라는 점도 간과할 수 없을 것이 다. 유아교사가 모든 교육 장면에서 이와 같은 인지양식 기반 교수법을 사용하는 것이 아니라 부분적으로(전체 교육시간의
일부에) 적용하더라도, 이러한 개인적 특성을 충분히 활용하 고 이용할 수 있도록 환경을 제공하는 것은 아동 주도의 교육 커리큘럼을 지향하는 오늘날의 시대에 함께 고려할 가치가 있 는 중요한 부분이라고 여겨진다. 따라서, 보다 정확한 아동의 인지적 특성 파악을 위한 노력(타당화된 검사 척도 개발 및 활 용, 계량화된 아동 행동 관찰 등), 아동에게 교육자료나 활동 의 선택권을 주는 시간의 확보, 보다 다양한 시청각 교육자료 가 존재하는 환경 구성 등을 통해, 비록 부분적으로 적용된다 하더라도, 아동의 인지적 개인 특성에 따른 보다 다각적이고 역동적인 유아교육의 실제를 구현해갈 수 있을 것이다. 그리 고 이는 아동 주도적 배움에 보다 도움이 되는 교수방안이 될 수 있을 것이다.

\section{Notes}

This article is a part of doctoral dissertation of Yun Hyun Pack (August 2021).

\section{Conflict of Interest}

No potential conflict of interest relevant to this article was reported.

\section{Ethics Statement}

All procedures of this research were reviewed by SNU IRB(No. 2006/002-024).

\section{References}

\section{In English}

Amadieu, F., Mariné, C., \& Laimay, C. (2011). The attentionguiding effect and cognitive load in the comprehension of animations. Computers in Human Behavior, 27(1), 36-40. doi:10.1016/j.chb.2010.05.009

Baddeley, A. D., \& Hitch, G. J. (1974). Working memory. In G. A. Bower (Ed.), Recent advances in learning and motivation (Vol. 8, pp. 47-89). New York: Academic Press.

Case, R. (1985). Intellectual development: Birth to adulthood. New York: Academic Press. 
Cuevas, J. (2016). An analysis of current evidence supporting two alternate learning models: Learning styles and dual coding. Journal of Education Sciences \& Psychology, 6(68), 1-13.

Daneman, M., \& Carpenter, P. A. (1980). Individual differences in working memory and reading. Journal of Verbal Learning and Verbal Behavior, 19(4), 450-466. doi:10.1016/S00225371(80)90312-6

De Koning, B. B., Tabbers, H. K., Rikers, R. M., \& Paas, F. (2010). Attention guidance in learning from a complex animation: Seeing is understanding? Learning and Instruction, 20(2), 111-122. doi:10.1016/j.learninstruc.2009.02.010

Dehaene, S., Changeux, J.-P., Naccache, L., Sackur, J., \& Sergent, C. (2006). Conscious, preconscious, and subliminal processing: A testable taxonomy. Trends in Cognitive Sciences, 10(5), 204-211. doi:10.1016/j.tics.2006.03.007

Eitel, A., Scheiter, K., Schüler, A., Nyström, M., \& Holmqvist, K. (2013). How a picture facilitates the process of learning from text: Evidence for scaffolding. Learning and Instruction, 28, 48-63. doi:10.1016/j.learninstruc.2013.05.002

Fan, J., McCandliss, B. D., Sommer, T., Raz, A., \& Posner, M. I. (2002). Testing the efficiency and independence of attentional networks. Journal of Cognitive Neuroscience, 14(3), 340-347. doi:10.1162/089892902317361886

Florax, M., \& Ploetzner, R. (2010). What contributes to the splitattention effect? The role of text segmentation, picture labelling, and spatial proximity. Learning and Instruction, 20(3), 216-224. doi:10.1016/j.learninstruc.2009.02.021

Gathercole, S. E. (1999). Cognitive approaches to the development of short-term memory. Trends in Cognitive Sciences, 3(11), 410-419. doi:10.1016/S1364-6613(99)01388-1

Gathercole, S. E., Alloway, T. P., Willis, C., \& Adams, A.M. (2006). Working memory in children with reading disabilities. Journal of Experimental Child Psychology, 93(3), 265-281. doi:10.1016/j.jecp.2005.08.003

Gathercole, S. E., Pickering, S. J., Ambridge, B., \& Wearing, H. (2004). The structure of working memory from 4 to 15 years of age. Developmental Psychology, 40(2), 177-190. doi:10.1037/0012-1649.40.2.177

Ginns, P. (2006). Integrating information: A meta-analysis of the spatial contiguity and temporal contiguity effects. Learning and Instruction, 16(6), 511-525. doi:10.1016/ j.learninstruc.2006.10.001

Grigorenko, E. L., \& Sternberg, R. J. (1995). Thinking styles. In D. H. Saklofske \& M. Zeidner (Eds.), International handbook of personality and intelligence (pp. 205-229). New York: Plenum Press.

Gudnason, J. (2017). Learning styles in education: A critique. Retrieved from ERIC database. (EJ1230420)

Jaeger, A. J., \& Wiley, J. (2014). Do illustrations help or harm metacomprehension accuracy? Learning and Instruction, 34, 58-73. doi:10.1016/j.learninstruc.2014.08.002
Mammarella, N., Fairfield, B., \& Di Domenico, A. (2013). When spatial and temporal contiguities help the integration in working memory: "A multimedia learning" approach. Learning and Individual Differences, 24, 139-144. doi:10.1016/j.lindif.2012.12.016

Mayer, R. E. (2003). The promise of multimedia learning: Using the same instructional design methods across different media. Learning and Instruction, 13(2), 125-139. doi:10.1016/ S0959-4752(02)00016-6

Mayer, R. E., \& Anderson, R. B. (1992). The instructive animation: Helping students build connections between words and pictures in multimedia learning. Journal of Educational Psychology, 84(4), 444-452. doi:10.1037/0022-0663.84.4.444

Mayer, R. E., \& Estrella, G. (2014). Benefits of emotional design in multimedia instruction. Learning and Instruction, 33, 12-18. doi:10.1016/j.learninstruc.2014.02.004

Mayer, R. E., \& Moreno, R. (2002). Aids to computer-based multimedia learning. Learning and Instruction, 12(1), 107119. doi:10.1016/S0959-4752(01)00018-4

Mayer, R. E., \& Moreno, R. (2003). Nine ways to reduce cognitive load in multimedia learning. Educational Psychologist, 38(1), 43-52. doi:10.1207/S15326985EP3801_6

Mayer, R. E., \& Sims, V. K. (1994). For whom is a picture worth a thousand words? Extensions of a dual-coding theory of multimedia learning. Journal of Educational Psychology, 86(3), 389-401. doi:10.1037/0022-0663.86.3.389

NAEYC. (1986). A position statement of the National Association for the Education of Young Children: Developmentally appropriate practice in early childhood programs serving children birth through age eight. Washington, DC: Author.

Nevo, E., \& Breznitz, Z. (2013). The development of working memory from kindergarten to first grade in children with different decoding skills. Journal of Experimental Child Psychology, 114(2), 217-228. doi:10.1016/j.jecp.2012.09.004

Peterson, E. R., Rayner, S. G., \& Armstrong, S. J. (2009). Researching the psychology of cognitive style and learning style: Is there really a future? Learning and Individual Differences, 19(4), 518-523. doi:10.1016/j.lindif.2009.06.003

Pickering, S. J., Gathercole, S. E., \& Peaker, S. M. (1998). Verbal and visuospatial short-term memory in children: Evidence for common and distinct mechanisms. Memory and Cognition, 26(6), 1117-1130. doi:10.3758/bf03201189

Plass, J. L., Chun, D. M., Mayer, R. E., \& Leutner, D. (1998). Supporting visual and verbal learning preferences in a second-language multimedia learning environment. Journal of Educational Psychology, 90(1), 25-36. doi:10.1037/00220663.90.1.25

Plass, J. L., Chun, D. M., Mayer, R. E., \& Leutner, D. (2003). Cognitive load in reading a foreign language text with multimedia aids and the influence of verbal and spatial abilities. Computers in Human Behavior, 19(2), 221-243. 
doi:10.1016/S0747-5632(02)00015-8

Rayner, S., \& Riding, R. (1997). Towards a categorisation of cognitive styles and learning styles. Educational Psychology, 17(1-2), 5-27. doi:10.1080/0144341970170101

Riding, R. J., \& Ashmore, J. (1980). Verbalizer-imager learning style and children's recall of information presented in pictorial versus written form. Educational Studies, 6(2), 141-145. doi:10.1080/0305569800060204

Riding, R., \& Rayner, S. (1998). Cognitive styles and learning strategies. London: David Fulton Publishers.

Rohrer, D., \& Pashler, H. (2012). Learning styles: Where's the evidence? Medical Education, 46(7), 634-635. doi:10.1111/ j.1365-2923.2012.04273.x

Smyth, M. M., \& Scholey, K. A. (1996). The relationship between articulation time and memory performance in verbal and visuospatial tasks. British Journal of Psychology, 87(2), 179192. doi:10.1111/j.2044-8295.1996.tb02584.x

Sorden, S. D. (2005). A cognitive approach to instructional design for multimedia learning. Informing Science Journal, 8, 263279. doi: $10.28945 / 498$

Teixeira, R. A. A., Zachi, E. C., Roque, D. T., Taub, A., \& Ventura, D. F. (2011). Memory span measured by the spatial span tests of the Cambridge Neuropsychological Test Automated Battery in a group of Brazilian children and adolescents. Dementia Neuropsychologia, 5(2), 129-134. doi:10.1590/ S1980-57642011DN05020012

Thomas, P. R., \& McKay, J. B. (2010). Cognitive styles and instructional design in university learning. Learning and Individual Differences, 20(3), 197-202. doi:10.1016/j.lindif.2010.01.002

Yue, C., Kim, J., Ogawa, R., Stark, E., \& Kim, S. (2013). Applying the cognitive theory of multimedia learning: An analysis of medical animations. Medical Education, 47(4), 375-387. doi: $10.1111 /$ medu. 12090

\section{In Korean}

Byun, Y.-K. (1999). Principles of an individualized instruction system development. Teacher Education Research, 37, 49-63.

Chang, U. H. (1998). Individual differences and problems of group instruction. Education Research, 17(1), 81-100.

Choi, Y.-W. (2014). A study of sensory processing, attention, emotional-behavioral characteristics for children with anxiety disorder (Master's thesis). Retrieved from http://www.riss. $\mathrm{kr} /$ link?id=T13422315

Do, K. S., \& Cha, Y.-Y. (2008). Effects of visual working memory capacity and the type and contents of graphic annotation on multimedia English learning. Korean Journal of Cognitive Science, 19(4), 369-396. doi:10.19066/ cogsci.2008.19.4.002

Do, K. S., \& Hwang, H.-R. (2006). Cognitive style and presentation order on retention and integration of information in multimedia learning. Korean Journal of Cognitive Science, 17(3), 231-253.

Kang, E.-S. (1993). The research of day care teachers' recognition on developmentally appropriate practice (Master's thesis). Retrieved from http://www.riss.kr/link?id=T2169943

Kim, E.-A. (2011). A study on the cognitive load of visual and verbal learners in scientific classifying activities (Doctoral dissertation). Retrieved from http://www.riss.kr/ link?id=T12518153

Kim, E.-J., Park, S.-D., \& Kim, K.-C. (2011). The analysis of smart phone application for early childhood based on cognitive theory. Journal of Korea Game Society, 11(4), 163174. doi:10.7583/JKGS.2011.11.4.163

Kim, J. Y., \& Baek, Y. M. (2007). The differences of memory defect and executive function in normal children and ADHD children. Korea Journal of Counseling, 8(1), 333349. doi:10.15703/kjc.8.1.200703.333

Kim, T. G. (2006). A study on learning effectiveness of the educational game (Master's thesis). Retrieved from http://www.riss.kr/ link?id=T10658957

Korea Institute for Curriculum and Evaluation. (1998). 1998 Research report of Korea Institute for Curriculum and Evaluation (Research report RRC 1998-1). Chungcheongbuk-do: Korea Institute for Curriculum and Evaluation.

Lim, K. Y., \& Choi, A. J. (2017). A preliminary study to develop shortened complex working memory tasks in young normal adults: Related to simple working memory tasks. Journal of Speech-Language \& Hearing Disorders, 26(1), 47-55. doi: 10.15724/jslhd.2017.26.1.005

Ministry of Education. (2019a). Chodeunghakgyo gwahak 5-2 gyosayong jidoseo [초등학교 과학 5-2 교사용 지도서]. Seoul: Ministry of Education.

Ministry of Education. (2019b). Chodeunghakgyo gwahak 6-1 gyosayong jidoseo [초등학교 과학 6-1 교사용 지도서]. Seoul: Ministry of Education.

Moon, H. O., \& Kang, M.-H. (1995). Adongjungsim-gyoyukgwajeongui heureum-e daehan gochal [아동중심교육과정의 흐름에 대한 고찰]. Collected Papers of Sorabol College, 9, 333-354.

Park, S.-H., \& Kwon, S. (2010). A Study on principles for developing cognitive load theory-based multimedia programs for preschoolers. Korean Journal of Children's Media, 9(1), 227-242.

Shin, M.-S., Do, R., Kim, S.-J., \& Park, M.-Y. (2010). Memory development: With children ranged from 4 to 12 Years. The Journal of the Korean Association of Psychotherapy, 2(1), 1323.

Yoo, J. Y., \& Lim, K. Y. (2015). The effect of working memory and short-term memory in language performance in normal adults. Journal of Speech-Language \& Hearing Disorders, 24(2), 19-26. doi:10.15724/jslhd.2015.24.2.002 
Yoon, Y. I. (2004). A comparative study on teachers' educational belief and teaching practices for early childhood education as appropriate to child development-Focused on day-care house and kindergarten teachers (Master's thesis). Retrieved from http://www.riss.kr/link?id=T9853968

\section{ORCID}

Yun Hyun Pack

$\mathrm{Na}$ Ya Choi

Bokyung Kim http://orcid.org/0000-0001-6956-2325

http://orcid.org/0000-0001-9189-9370

http://orcid.org/0000-0001-9132-7989

Received August 31, 2021

Revision received October 31, 2021

Accepted November 1, 2021 